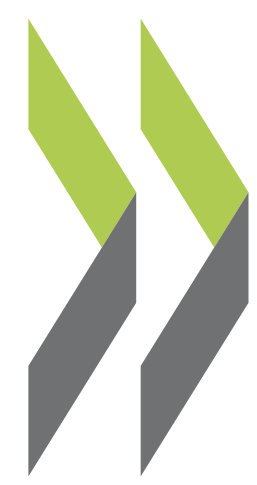

OECD Economics Department Working Papers No. 1467

\section{Benefit reform}

for employment and equal opportunity in Finland
Jon Pareliussen, Hyunjeong Hwang 
Organisation de Coopération et de Développement Économiques

Organisation for Economic Co-operation and Development

22-May-2018

ECONOMICS DEPARTMENT

English - Or. English

\section{BENEFIT REFORM FOR EMPLOYMENT AND EQUAL OPPORTUNITY IN FINLAND}

ECONOMICS DEPARTMENT WORKING PAPERS No. 1467

By Jon Kristian Pareliussen and Hyunjeong Hwang

OECD Working Papers should not be reported as representing the official views of the OECD or of its member countries. The opinion expressed and arguments employed are those of the author(s).

Authorised for publication by Álvaro Pereira, Acting Chief Economist, Economics Department.

All Economics Department Working Papers are available at www.oecd.org/eco/workingpapers.

JT03432171

This document, as well as any data and map included herein, are without prejudice to the status of or sovereignty over any territory, to the delimitation of international frontiers and boundaries and to the name of any territory, city or area. 
OECD Working Papers should not be reported as representing the official views of the OECD or of its member countries. The opinions expressed and arguments employed are those of the author(s).

Working Papers describe preliminary results or research in progress by the author(s) and are published to stimulate discussion on a broad range of issues on which the OECD works.

Comments on Working Papers are welcomed, and may be sent to the Economics Department, OECD, 2 rue André-Pascal, 75775 Paris Cedex 16, France, or by e-mail to eco.contact@oecd.org.

All Economics Department Working Papers are available at www.oecd.org/eco/workingpapers.

This document and any map included herein are without prejudice to the status of or sovereignty over any territory, to the delimitation of international frontiers and boundaries and to the name of any territory, city or area.

The statistical data for Israel are supplied by and under the responsibility of the relevant Israeli authorities. The use of such data by the OECD is without prejudice to the status of the Golan Heights, East Jerusalem and Israeli settlements in the West Bank under the terms of international law.

\section{(C) OECD (2018)}

You can copy, download or print OECD content for your own use, and you can include excerpts from OECD publications, databases and multimedia products in your own documents, presentations, blogs, websites and teaching materials, provided that suitable acknowledgment of OECD as source and copyright owner is given. All requests for commercial use and translation rights should be submitted to rights@oecd.org 


\section{ABSTRACT/RÉSUMÉ}

\section{Benefit reform for employment and equal opportunity in Finland}

The combination of different working-age benefits, childcare costs and income taxation creates complexity, reduces work incentives and holds back employment. Major disincentives in Finland are related to tapering rules for unemployment benefits, social assistance and the housing benefit, the extended unemployment benefit for older workers, the childcare fee structure and the homecare allowance. Improved benefit design combined with efficient activation policies can reduce complexity and remove the strongest disincentives while minimising adverse fiscal and social impacts. Replacing current benefits with a basic income would improve incentives for many, but with a drastic redistribution of income and likely increasing poverty as a result. Merging working-age benefits with similar aims and coordinating their tapering against earnings would on the other hand consistently improve work incentives and transparency, while preserving social protection. Once the new income registry comes online, linking benefit payments to real-time incomes, combined with strengthened work incentives, would make for a truly efficient and inclusive benefit system, fit for the future of work.

This Working Paper relates to the 2018 OECD Economic Survey of Finland (www.oecd.org/eco/surveys/economic-survey-finland.htm).

Keywords: welfare reform, basic income, universal credit, Finland, work incentives, inequality.

JEL classification codes: D31, H53, H55, J38.

$* * * * * * * * * * * * *$

\section{Réformer les prestations sociales pour favoriser l'emploi et l'égalité des chances en Finlande}

La combinaison des différentes prestations reçues par les personnes en âge de travailler, des coûts de garde d'enfants et de l'impôt sur le revenu crée de la complexité, réduit les incitations à travailler et restreint l'emploi. Les principales désincitations en Finlande sont liées aux règles de réduction des allocations chômage, d'aide sociale et de logement, à l'extension des allocations chômage pour les travailleurs âgés, à la structure des frais de garde d'enfants et à l'allocation de soins à domicile. L'amélioration de la conception des prestations, combinée à des politiques d'activation efficaces peut réduire la complexité et éliminer les désincitations les plus fortes, tout en minimisant les coûts fiscaux et sociaux. Le remplacement des prestations actuelles par un revenu de base améliorerait les incitations pour beaucoup, mais avec une redistribution drastique des revenus et, par conséquent, probablement une pauvreté accrue. La fusion des prestations reçues par les personnes en âge de travailler ayant des objectifs similaires et la coordination de leur réduction en fonction des revenus augmenteraient systématiquement les incitations à travailler et la transparence, tout en préservant la protection sociale. Une fois le nouveau registre des revenus mis en ligne, lier les versements de prestations aux revenus en temps réel, tout en renforçant les incitations à travailler, créerait un système de prestations réellement efficace et inclusif, adapté à l'avenir du travail.

Ce Document de travail se rapporte à l'Étude économique du Finlande 2018

(www.oecd.org/fr/eco/etudes/etude-economique-finlande.htm).

Mots-clés: réforme des prestations sociales, revenu de base, crédit universel, Finlande, incitations à travailler, inégalité.

JEL classification codes: D31, H53, H55, J38. 


\section{TABLE OF CONTENTS}

\section{BENEFIT REFORM FOR EMPLOYMENT AND EQUAL OPPORTUNITY IN FINLAND ....................6}

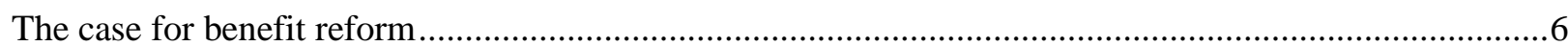

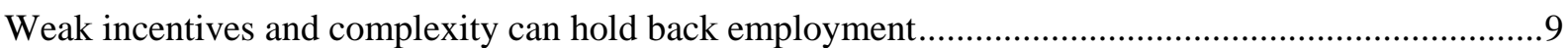

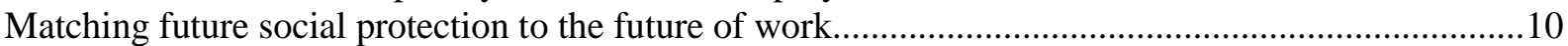

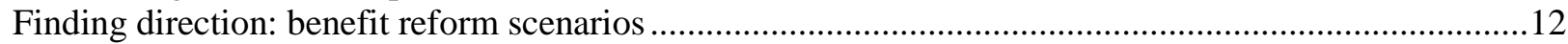

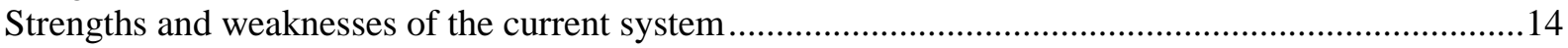

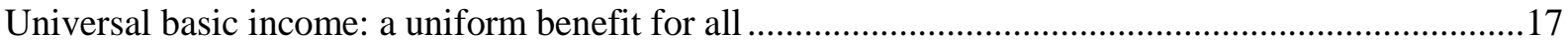

Universal credit: a uniform tapering rule for all existing benefits .....................................................19

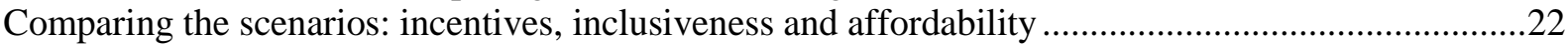

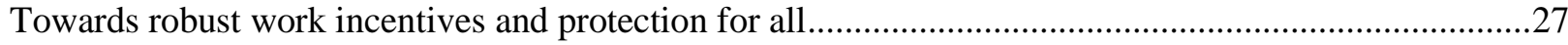

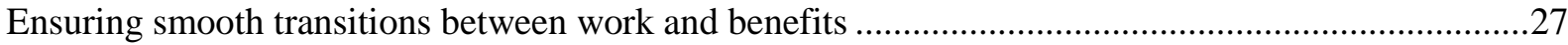

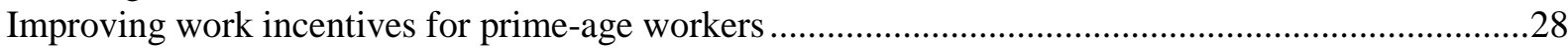

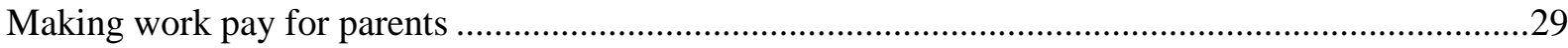

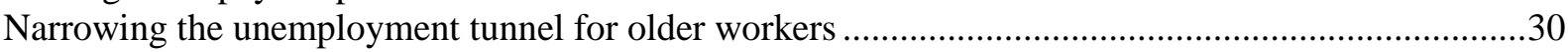

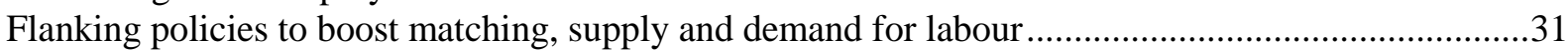

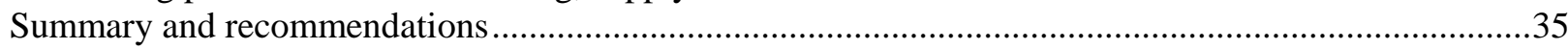

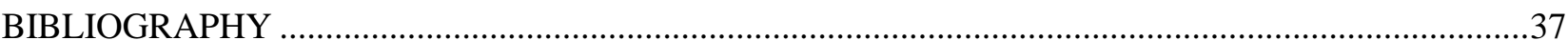

\section{Tables}

Opportunities and challenges associated with non-standard work .......................................................11

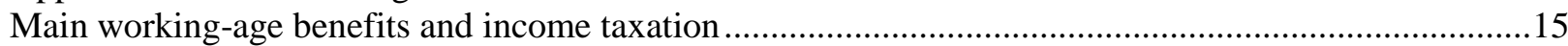

Comparative average effective tax rates, income-related unemployment insurance ...............................22

Comparative average effective tax rates, social assistance and housing benefit ....................................23

\section{Figures}

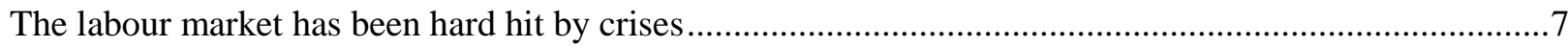

Employment is low compared to other Nordics across gender and age .................................................

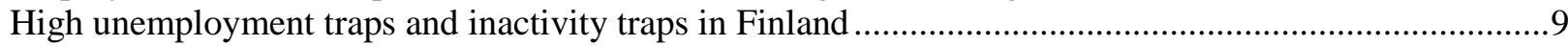

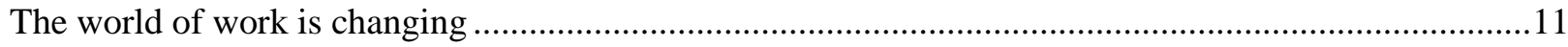

Net income and work incentives in the current benefit system ..........................................................13

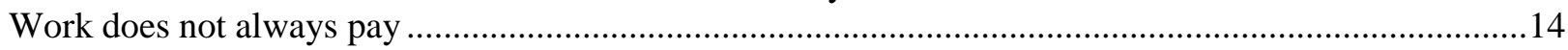

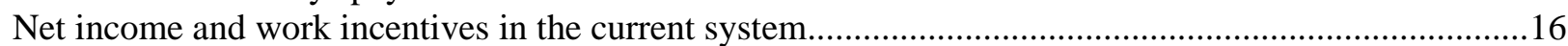

Existing cash support is targeted towards the poor in Finland...........................................................17

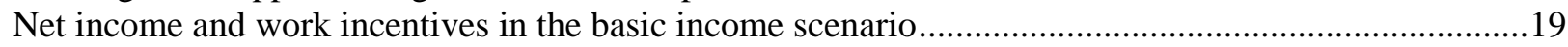

Net income and work incentives in the universal credit scenario .......................................................21

A basic income would reduce incomes in the bottom of the distribution .............................................24

A basic income scenario would alter the income distribution ............................................................25

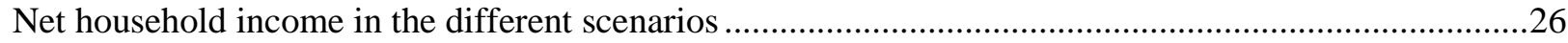

Exit rates spike immediately before unemployment benefit expiry ......................................................28

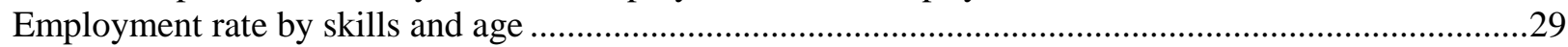

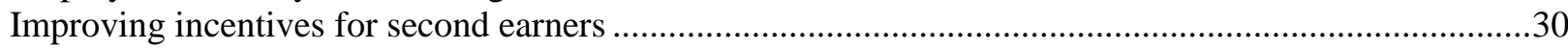


Shortening the unemployment tunnel increases employment substantially .31

Rising unemployment and budget cuts have put the employment service under strain

\section{Boxes}

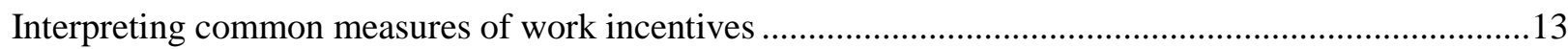

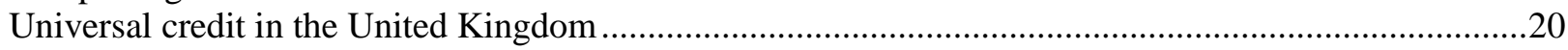

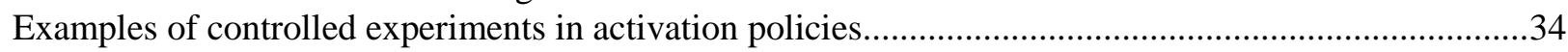




\title{
BENEFIT REFORM FOR EMPLOYMENT AND EQUAL OPPORTUNITY IN FINLAND
}

\author{
By Jon Kristian Pareliussen and Hyunjeong Hwang ${ }^{1}$
}

Working-age benefits in Finland are a patchwork of different schemes introduced and reformed over the years to cater to different needs, and previously administered at different levels of government. Notwithstanding a trend towards simplification and centralisation, complex interactions between different benefits and income taxation create unemployment and inactivity traps, compounded by schemes targeting older workers and families with children.

Technological progress induces important changes to working life, with an increasing share of freelance and part-time workers. Traditional benefit systems, such as the Finnish one, are built up around traditional employer-employee relationships, and lack the flexibility to adapt benefits to volatile incomes and frequent transitions in and out of work. Non-standard workers are therefore less likely to qualify for unemployment benefits and less likely to participate in activation policies. But technology also opens up opportunities. A simplified benefit system with stronger work incentives combined with real-time income reporting holds a great potential to facilitate transitions between benefits and work for people on standardand non-standard contracts alike.

However, creating a well-functioning system of social insurance and redistribution is a delicate balancing act in which work incentives must be weighed against social protection and impact on public finances. This paper presents and analyses different solutions to the challenges of complexity and disincentives on the backdrop of a rapidly changing world of work, and how different possible directions for future reform would affect the balance between incentives, inclusiveness and affordability, the policy trilemma at the heart of social insurance and redistribution policy.

These and similar analyses can help formulate a vision for social welfare in Finland and show a clear direction for benefit reform. However, major reorganisations can come with significant costs. Implementation should hence be stepwise, building on the existing system and institutional context, and important technical building blocks should be fully operational and well-tested before full roll-out.

The rest of the paper is structured as follows: Section two explains why reform of social benefits is needed in Finland. Strengths and weaknesses of the current benefit system are compared with two stylised reform scenarios in section three. Section four discusses the main reform priorities within the existing benefit system and labour market context. Recommendations and a summary of main findings are presented in section five.

\section{The case for benefit reform}

The employment rate is lower in Finland than in all the other Nordics, which is partly compensated in terms of total labour input by more hours worked per employee and a lower prevalence of part-time work. Cyclical factors play a role in explaining the employment rate gap. The Finnish labour market was particularly hard hit by the 1990s banking crisis, which coincided with the collapse of the Soviet Union, an important trading partner (Ahtiala and Junttila, 2015). This crisis had persistent effects on employment as early retirement policies introduced in the 1970s and 1980s, notably early old-age pension, unemployment pension and disability pension, were actively used to reduce labour supply (Gould and Saurama, 2017). More recently, employment growth was weakened by the slow recovery from the Great Recession, due to difficulties in the forestry industry, the collapse of Nokia and weak economic conditions in Russia (Figure 1). However, policy settings also hold back labour supply. The OECD Economic Survey of Finland 2016

\footnotetext{
${ }^{1}$ The authors, both working in the OECD Economics Department, would like to thank Heikki Viitamäki of the VATT Institute for Economic Research warmly for his contributions to this paper. Further gratitude is extended to Jukka Mattila, Ilari Keso, Kaisa Kotakorpi, Hanna Pesola, James Browne, Herwig Immervoll, Mathilde Pak, Christophe André, Vincent Koen and Asa Johansson for valuable comments and suggestions, and to Sisse Nielsen and Mercedes Burgos for secretarial assistance.
} 
ECO/WKP(2018)15

Figure 1. The labour market has been hard hit by crises

A. Employment rate ${ }^{1}$

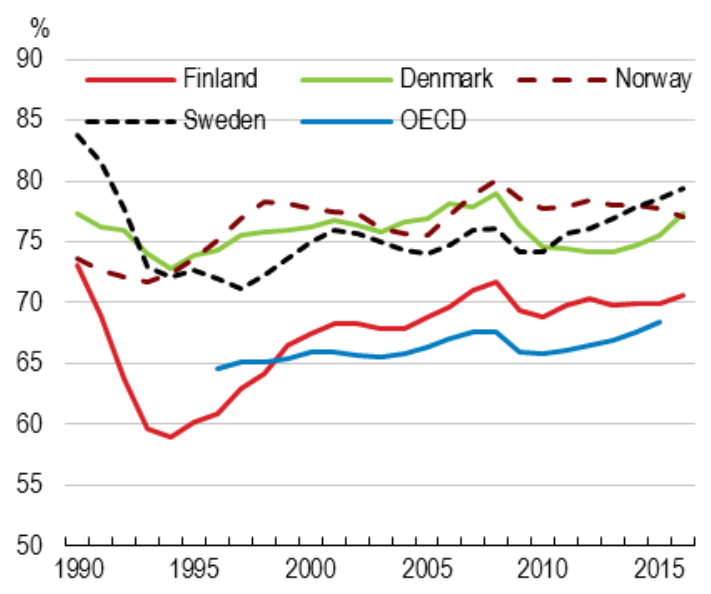

B. Potential and cyclical employment ${ }^{1}$

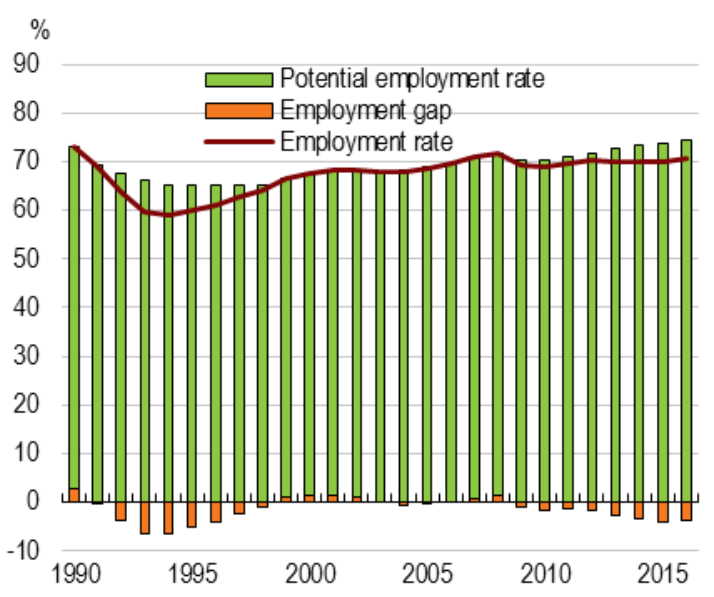

1. Percentage of population aged 15-64.

Source: OECD Economic Outlook database; and Labour Force Statistics.

points to a considerable potential to expand the labour force by speeding up the labour market entry of youth, postponing the exit of older workers, improving work incentives and activation policies for the unemployed and increasing the labour market participation of women of childbearing age.

Higher employment fosters equity and well-being in a number of ways. Raising employment increases equity directly, as those out of work face the highest risk of poverty, and indirectly, as it generates tax revenue, which can be used to finance public services and the social safety net. Well-being is also higher for the employed, who on average enjoy higher purchasing power, better housing conditions, better health and better opportunities to interact socially. Furthermore, higher female employment can improve work-life balance for both genders, if work and domestic responsibilities are shared more equally. The government has the ambition to increase the employment rate of the population aged 15-64 to 72\% and reduce the unemployment rate to 5\% by the end the end of the parliamentary term in 2019 (Ministry of Finance, 2014). The current economic upturn increases the chances of reaching this bold employment target, but this remains challenging. Even if employment reaches $72 \%$, a significant untapped potential would remain. Moreover, even higher employment is needed on a lasting basis to counter the impact of ageing and strengthen public finances (OECD Economic Survey of Finland, 2018; 2016; Economic Policy Council, 2017; European Commission, 2017).

Women's employment rate is almost at the level of men's in Finland, making for the second lowest gender employment gap in the OECD. Nonetheless, employment rates of both men and women are lower in Finland than in the other Nordics, and male employment is lower than the OECD average (Figure 2, Panels A and B). Men of all ages are less likely to be employed than in the other Nordics, but especially so in older cohorts. Women aged 40 to 60 do relatively well, with employment rates close to the Nordic average. In contrast, women in childbearing age are much less likely to be employed than in Sweden and Norway, despite taxation applying to individual incomes and generous parental leave and childcare arrangements in all three countries. Accounting for different statistical classification of Swedish and Finnish women in maternity leave reduces the difference, but a considerable gap remains (Pärnänen and Kambur, 2017). The employment rate of young adults is lower in Finland than in Norway and Denmark, despite higher tertiary enrolment in those countries (Panel C). Given the high attendance in upper secondary vocational education and training (VET), Finland should target youth employment rates comparable to Norway, Germany and Denmark. Indeed, individuals with a vocational education enter the Finnish labour market fairly smoothly at a young age, but their work-specific skills may become obsolete 
as society changes, increasing the likelihood of early labour market exit (OECD Economic Survey of Finland, 2016). Certain immigrant groups, notably humanitarian immigrants from Afghanistan, Iraq and Somalia, have very low employment rates and earnings, even many years after arrival (Sarvimäki, 2017).

Figure 2. Employment is low compared to other Nordics across gender and age

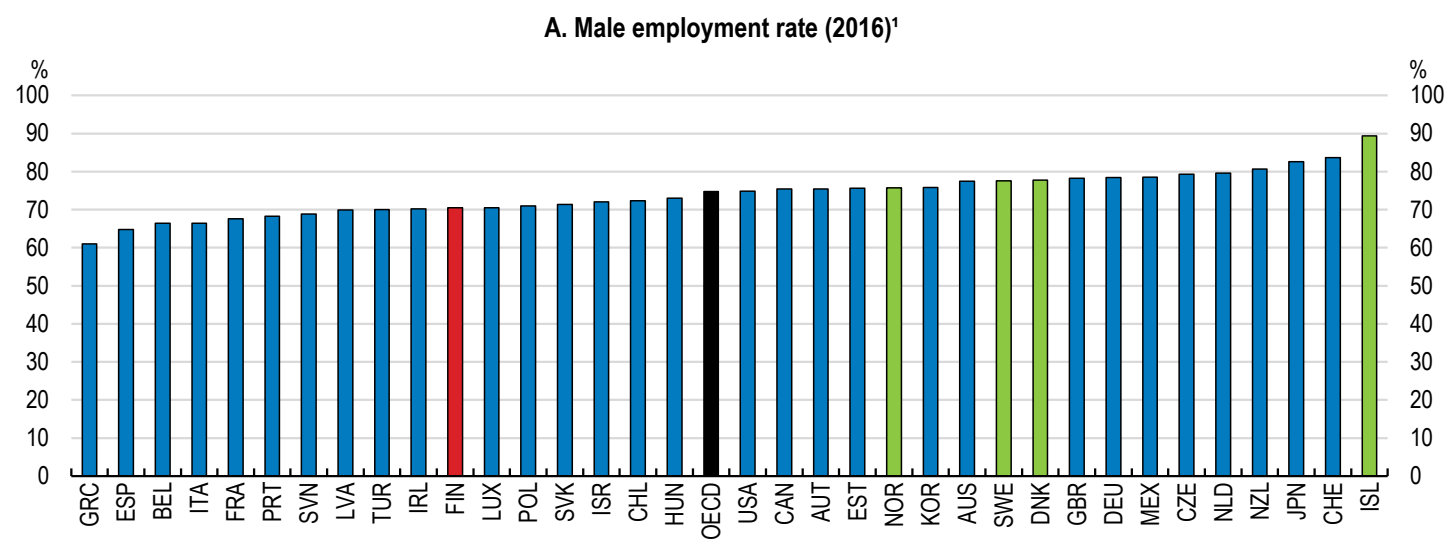

B. Female employment rate (2016) ${ }^{1}$

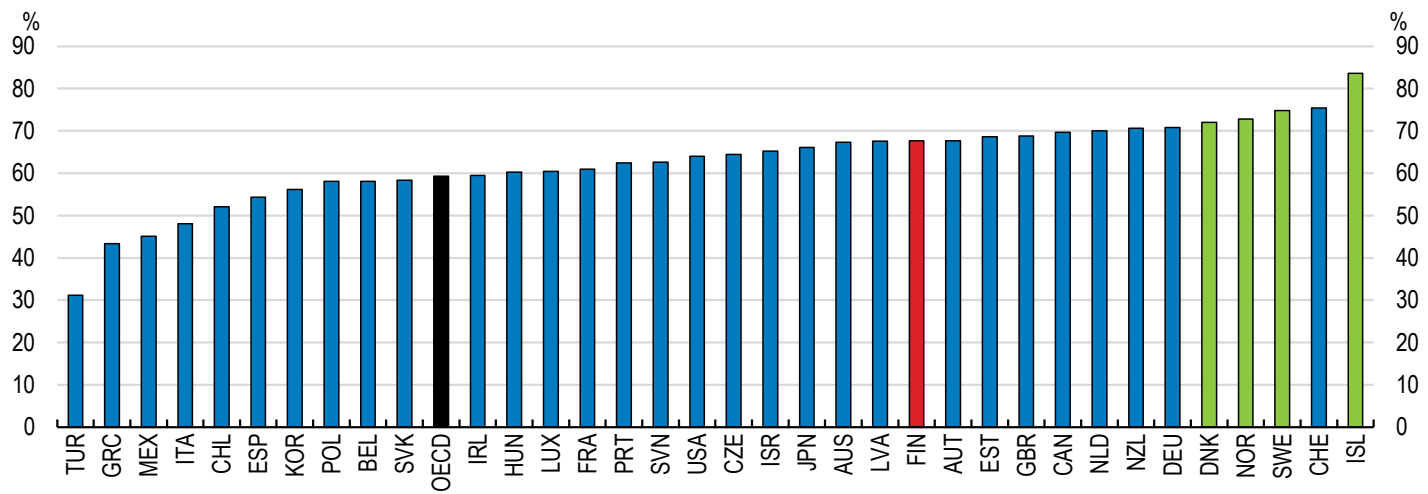

C. Employment gap to Nordics (2016) ${ }^{2}$
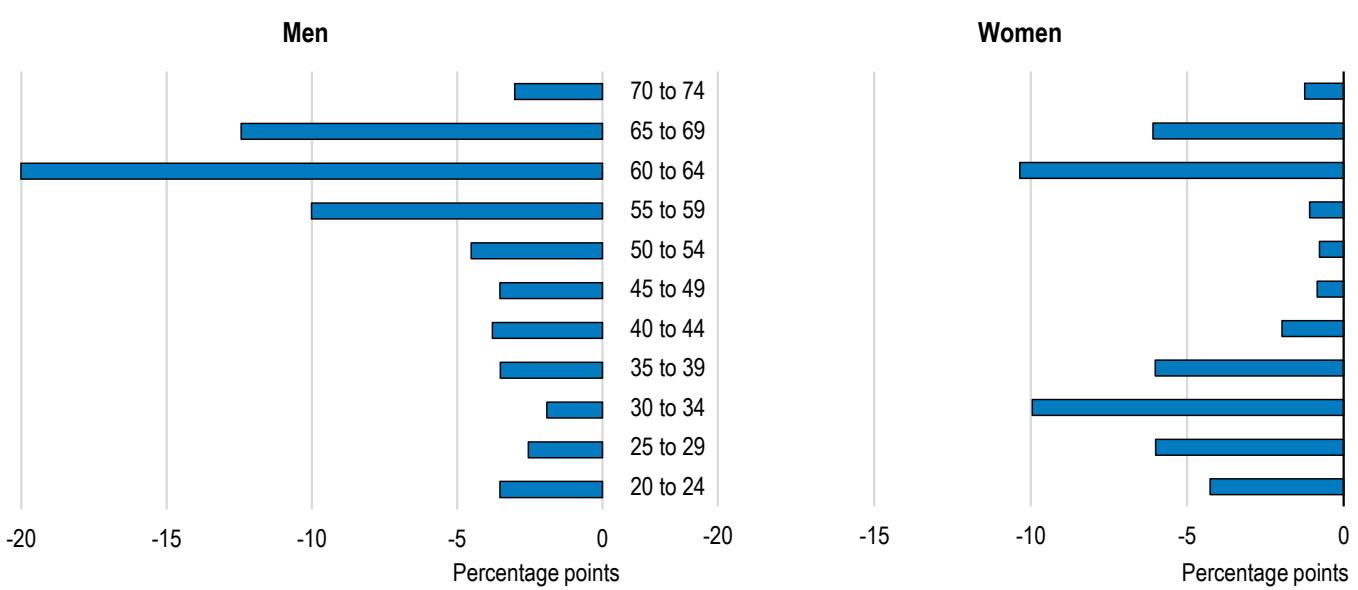

1. Percentage of population aged $15-64$.

2. Difference in employment rates between Finland and the Nordic average (Denmark, Norway, and Sweden), within each agegender sub-group.

Source: OECD Labour Force Statistics database. 
A number of recommendations made in the OECD Economic Survey of Finland 2016 to improve the labour market functioning, including with respect to education, activation policy, employment protection legislation and wage bargaining, have since been addressed by the government and social partners. Important steps have also been taken to improve work incentives for the unemployed. But more needs to be done. A complex system built around the traditional employer-employee model will likely be increasingly challenged in a rapidly changing world of work, and work incentives can still be very weak for many individuals when different benefits and taxes interact.

\section{Weak incentives and complexity can hold back employment}

The OECD Economic Survey of Finland 2016 points to relatively high benefit levels with long duration in combination with relatively weak activation as a partial explanation as to why labour market outcomes fall short of those in the other Nordics. However important, these average measures are only rough indicators of the problems of the current Finnish benefit system, and a more detailed analysis is needed to correctly gauge work incentives and set out directions for future reform.

\section{Figure 3. High unemployment traps and inactivity traps in Finland}
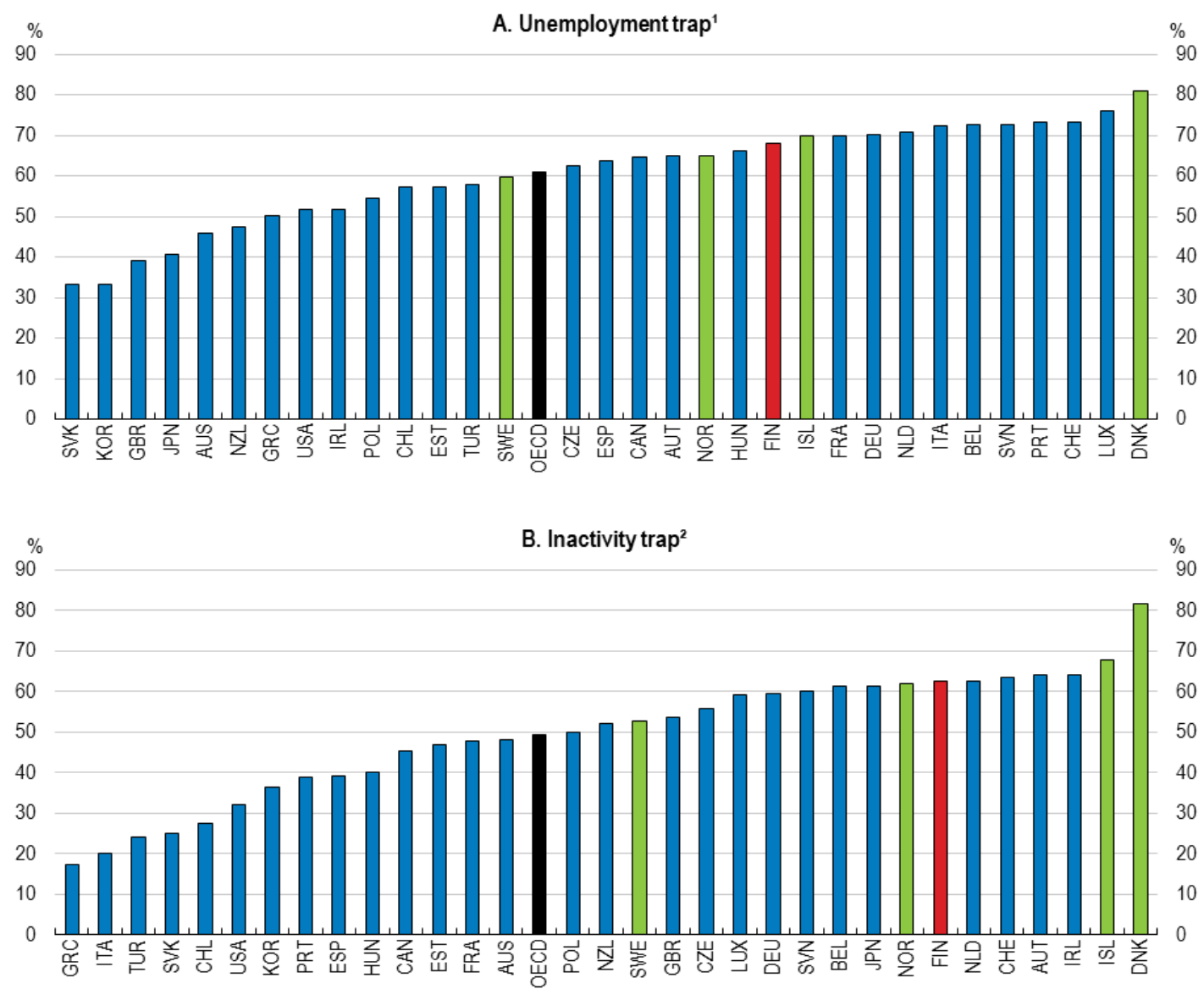

1. Average effective tax rate (AETR) in the initial phase of unemployment for an individual entitled to unemployment insurance but not to means-tested benefits. The AETR measures the proportion of earnings that are "taxed away" by income taxation and loss of benefits when moving from inactivity to full-time work. AETRs are modelled as an average for six household types: single; single parent; couple, inactive spouse, no children; couple, inactive spouse, two children; couple, working spouse, no children, and; couple, working spouse, two children; and five earning levels: $33 \%, 50 \%, 67 \%$, $100 \%$, and $150 \%$ of the national average wage. Households with children are assumed to have two children aged four and six. Child-related benefit- and tax rules are taken into account. Childcare related costs and benefits are not. Reference year 2015.

2. As in Panel A, but for an individual entitled to means-tested social assistance and housing benefits, but no unemployment insurance.

Source: OECD TaxBen models. 
On the surface, incentives to go from unemployment (Figure 3, Panel A) or inactivity (Panel B) to work are weaker than the OECD average, but stronger than in a number of countries. However, these average calculations ignore that the pay-off of going from inactivity to work can be very low or even negative in a number of situations. These incentive problems are created by interactions between different benefits and income taxation, as argued later in this paper. Unemployment benefits are available in three forms, tapered on individual income. Housing benefits and social assistance are means-tested on family income. Social assistance can provide a top-up to the other benefits, and it contains a housing element with rules differing from the ordinary housing benefit. All the benefits share the same main goals of providing income security and adequate living standards for the jobless, and they all account for children and family size in various ways. As of 2017, all the benefits are administered by the Social Insurance Institution of Finland (Kela), except for income-related unemployment insurance, which is paid by unemployment funds, but coordinated with the unemployment benefits administered by Kela and subject to the same set of activation requirements. Disincentives from the uncoordinated tapering of these benefits with largely overlapping aims are compounded by childcare related fees and benefits, as well as extended unemployment insurance eligibility for older workers ("the unemployment tunnel").

These incentive traps, discouraging individuals on benefits to take up work or increase work efforts, are compounded by what can be termed "bureaucratic traps", where the complexity of benefit rules combined with administrative practices create uncertainty about the amount and timing of cash receipts, further reducing the attractiveness of work efforts for risk-adverse, often cash-strapped, individuals (European Commission, 2017). A change of circumstances usually leads to benefits being frozen while eligibility is reassessed and benefits re-calculated by Kela and unemployment funds on the request of the employment service caseworker. Facing the real or perceived risk of losing eligibility or delayed benefit payments combined with liquidity constraints can thus render temporary or part-time work unattractive even if monetary incentives are decent (Pareliussen et al., 2018a; European Commission, 2017; Economic Policy Council, 2017).

\section{Matching future social protection to the future of work}

An increasing share of non-standard work arrangements poses further challenges to welfare systems (Figure 4, panels A and B). Digitalisation has led to profound changes in working lives over the past few decades. It has enabled automation of routine tasks and facilitated the expansion of global value chains, important forces behind the decline of routine manufacturing jobs (Goos et al., 2009; Eurofound, 2017; OECD, 2017a). Despite being less exposed than most OECD countries, more than 25\% of Finnish jobs face the risk of significant change from automation going forward (Figure 4, panel C; OECD, 2016a). Platform-based delivery of goods (e.g. Amazon) and information (e.g. Google and Facebook) has been around for a while, but more recently the platform-based delivery of physical services, such as transportation and accommodation (e.g. Uber and AirBnB) has become mainstream. Platforms for a number of other services, such as financial services, legal advice, coding, design, personal services and handyman services have also emerged. Such trends are likely to continue, leading to continued structural changes in working lives.

New technologies bring opportunities to use society's resources more effectively, but also challenges (Table 2.1). Freelance work ("the gig economy") and other forms of non-standard employment are not new, and the platform economy represents only a small, albeit growing share of total employment. Even so, digital service platforms will change firms' employment decisions at the margin, and a rising share of freelance work should be expected going forward. Improving protection of freelancers and self-employed to put them as far as possible on an equal footing with regular workers is a major challenge to social protection systems across the OECD (OECD, 2016a; OECD, 2017a). But the challenge is not insurmountable. Some countries, for example Belgium, have systems where specific categories of self-employed are entitled to an unemployment-like benefit in case of bankruptcy. In addition, freelance and platform work should be accommodated by public employment services, with flexible benefit adjustments, continued eligibility and demands for job-search and other activation measures adapted for individuals engaging in part-time platform work while unemployed. Indeed, technology is also an integral part of the solution to 
these challenges as it can facilitate automation of benefit payments, adjusted in real-time to individual earnings. Automating parts of the public employment service, such as regular activity reporting, can free human resources for coaching, mentoring and individually tailored activation.

\section{Figure 4. The world of work is changing}
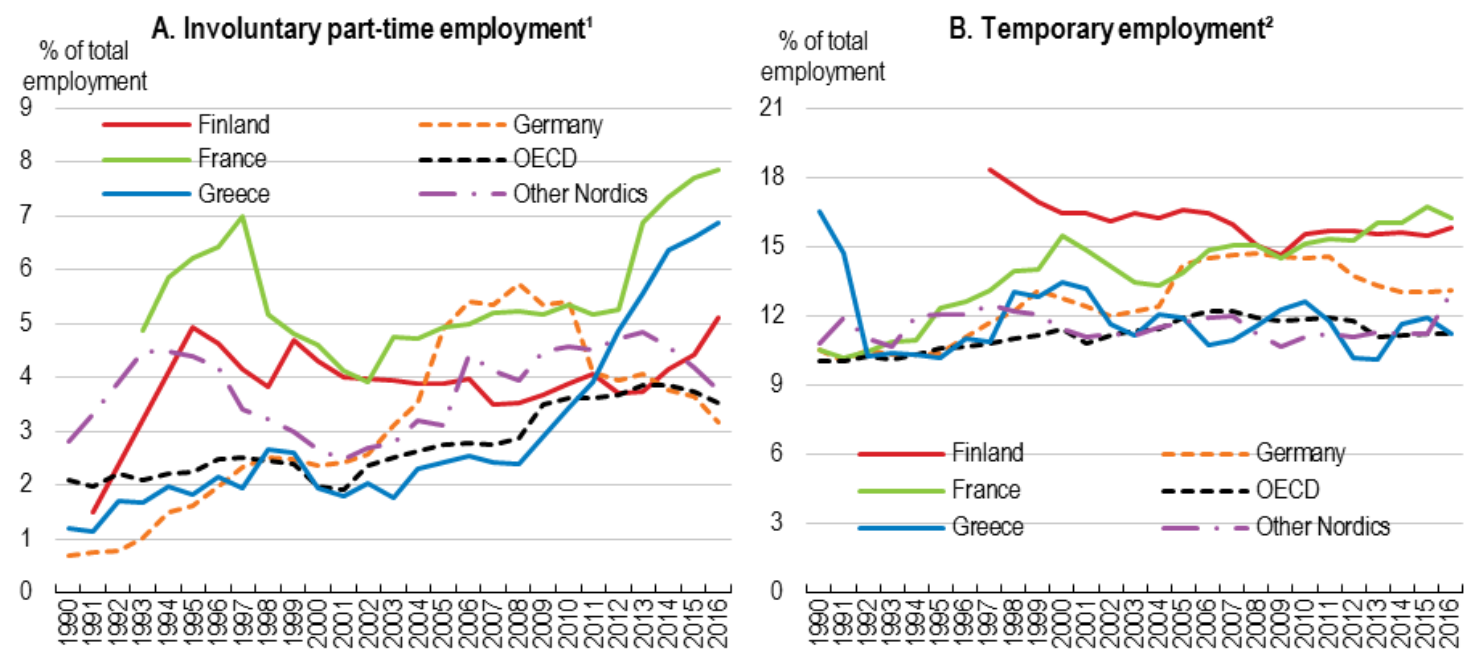

C. The risk of automation in OECD countries ${ }^{3}$

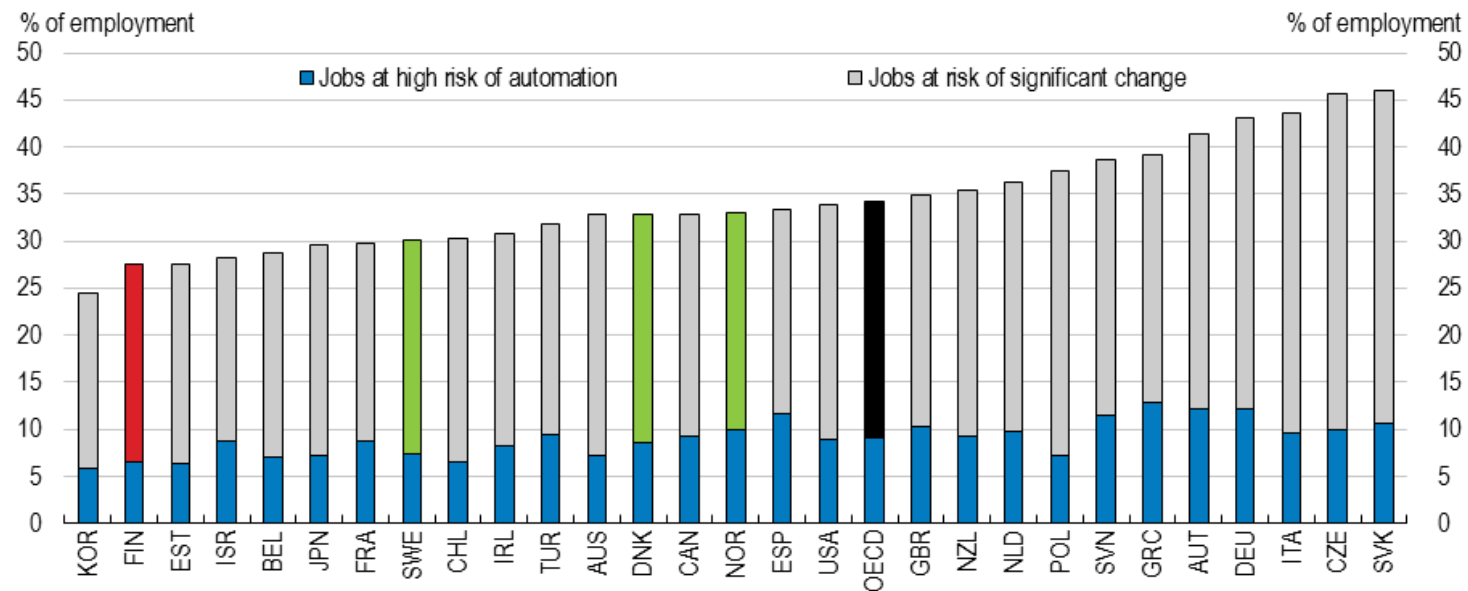

1. Involuntary part-time employment is defined as people who work part-time because full-time work is not available.

2. Temporary employment includes wage and salary workers whose job has a pre-determined termination date.

3. Based on the analysis of the task content of individual jobs using the OECD Adult Skills Survey (PIAAC). Jobs are at high risk of automation if the likelihood of being automated is at least $70 \%$. Jobs at risk of significant change are those with the likelihood of being automated estimated at between 50 and 70\%. For more details, see OECD Employment Outlook 2017.

Source: OECD Labour Force Statistics database; and OECD Employment Outlook 2017, OECD Publishing, Paris.

Table 1. Opportunities and challenges associated with non-standard work

\begin{tabular}{ll}
\hline Opportunities & Challenges \\
\hline Labour markets & $\begin{array}{l}\text { Non-standard work, small jobs, micro tasks } \\
\text { Flexible access to work and income opportunities }\end{array}$ \\
$\begin{array}{l}\text { Possible inclusion of marginal groups in the labour force } \\
\text { Low barriers to work entry and exit }\end{array}$ & $\begin{array}{l}\text { Less employer-sponsored training of workers } \\
\text { Working conditions }\end{array}$ \\
$\begin{array}{ll}\text { Flexible working time (and space for digital services) } \\
\text { Autonomous work organisation }\end{array}$ & $\begin{array}{l}\text { Job insecurity, higher unemployment risk } \\
\text { Potential productivity gains }\end{array}$ \\
\hline
\end{tabular}

Source: OECD, 2016a. 
Digitalisation splits processes into specialised tasks which can be bought from different providers. Buyers of platform services thus have incentives to buy services from freelancers with high customer ratings on similar tasks in the past, and freelancers gain from specialising. The incentives to broaden skills through new work experience can therefore be limited in the "gig economy". Furthermore, the employer's incentive to invest in training of their employees is very weak for platform workers, notwithstanding some examples of platforms offering training. Skill development will therefore mostly need to be initiated by individuals. Online learning platforms can help, as they provide a more flexible way of learning, but are a long way from replacing flexible and affordable education opportunities in the public education system throughout working life (OECD, 2016a). Finland, renowned for its excellent, publicly funded education system, is taking steps in the direction of modular upper secondary and tertiary education, an important effort to adapt to the challenges coming from digitalisation, longer careers and changing skill needs.

Unionisation of self-employed platform workers could strengthen their voice, increase their rights and help them insure against some adverse risks. Experiences from other freelance unions, such as journalists, artists and lawyers can provide a basis, but reaching platform workers would require some new thinking about the role and shape of trade unions and freelancers' legal right to collective wage bargaining. Across OECD countries, several projects are underway, spanning from bottom-up initiatives to create app-based unions and lawsuits to protect platform-workers' rights, to top-down initiatives from trade union confederations (ETUC, 2016; Taylor Review, 2017).

\section{Finding direction: benefit reform scenarios}

Complex benefit systems creating multiple stumbling-blocks to employment today, and ill-adapted to the future of work, need to be seen in light of their history and the multitude of individual risks and circumstances they are targeting. The main motive for insurance benefits such as pensions, sickness and unemployment insurance, is to smooth individual income over the lifetime in the face of changing life situations and a multitude of adverse risks. Assistance benefits such as social assistance, housing benefits and minimum pensions, redistribute tax revenue to individuals in need and benefit low-income individuals disproportionally. In practice, social protection systems in all OECD countries involve a mix of redistribution between rich and poor and redistribution over the lifecycle (Causa and Hermansen, 2017).

A good system should contribute to employment, via strong work incentives, offer strong social protection and be affordable. However, these goals form a policy trilemma: high benefit levels can only be combined with strong work incentives if benefits are withdrawn (tapered) slowly against income from work, and generosity combined with slow tapering has a significant fiscal cost. But good design and efficient flanking policies can ease this trade-off: removal of incentive traps combined with efficient activation policies will boost employment, partly offsetting the fiscal cost of higher average benefit payments. It is therefore necessary to find a balance between an adequate initial benefit level, an adequate speed of tapering, efficient benefit design and other measures encouraging work.

In looking for the right balance of benefit levels it is worth keeping in mind that the current systems in Finland and elsewhere differentiate payments to different groups for good reasons, with some groups, such as lone parents, receiving higher payments because of higher need. This targeting has been built up through political processes spanning several decades, and hence reflect a society's social preferences. Furthermore, Finland relies on a so-called "flexicurity model", where constructive labour relations and openness to structural change depends on adequate income protection for those who lose out, notably the unemployed. Last but not least, unemployment insurance is an important automatic stabiliser for economic activity.

The monetary pay-off is not the only factor affecting individual decisions to take up work or increase work efforts. Work-related expenses, spouse income, the number and age of children, regional housing price differences and individual preferences will for example play important roles. For these reasons and because of the need for balancing incentives with inequality and affordability, it is impossible to determine a single optimal incentive level for any individual. However, marginal effective tax rates and/or average effective tax rates (Box 1) exceeding 100\% are clearly too high and should be avoided, as this means that 
individuals will lose money from taking up work or working more. Nonetheless, some OECD countries fail to meet this simple rule of thumb for some specific individual circumstances, and average effective tax rates above $80 \%$, which also constitute weak incentives, are quite common (Figure 6).

\section{Box 1. Interpreting common measures of work incentives}

This paper uses three common measures to evaluate work incentives and illustrate the causes of inactivity- and incentive-traps.

Net income, the income an individual is left with after paying taxes and receiving transfers, is a natural place to start when evaluating the effect of taxes and benefits. The level and composition of net income are interesting in themselves, but the slope of the net income curve as a function of work income (or work hours) also gives considerable information about the strength and causes of incentives to take up work and marginally increase work.

The average effective tax rate (AETR) measures how much of the additional earnings from moving into work will be lost to taxes, charges and benefit withdrawal (tapering). For example, an AETR of $60 \%$ at three workdays a week means that if an individual goes from zero to three workdays a week, her net income will increase by $40 \%$ of her work income, while 60 cents in a euro will be taxed or taken away by the tapering of benefits.

The marginal effective tax rate (METR) is a common measure of incentives to progress in work. It measures the marginal increase in net income resulting from a marginal increase in work income. For example, a METR of $80 \%$ at three workdays a week means that if an individual increases the amount of hours marginally above three days, she will keep $20 \%$ of the additional pay, or 20 cents for each additional euro earned.

The interpretation of these measures is illustrated in Figure 5, showing the situation of a single person entitled to unemployment insurance in Finland. Unemployment benefits are reduced by $50 \%$ of additional earnings after a threshold at less than one workday a week. Benefit withdrawal and income taxation together result in a METR around $100 \%$ from about 2 workdays a week until unemployment insurance is entirely withdrawn at four workdays a week. The "cliff-edge" loss of benefits at four days of work is reflected in a sudden jump in the AETR, as well as a pronounced spike in the METR. In sum, these figures show good work incentives working part-time for up to two workdays, and weak incentives to work more. These incentive issues are clearly caused by the design of the unemployment insurance.

Figure 5. Net income and work incentives in the current benefit system ${ }^{1}$
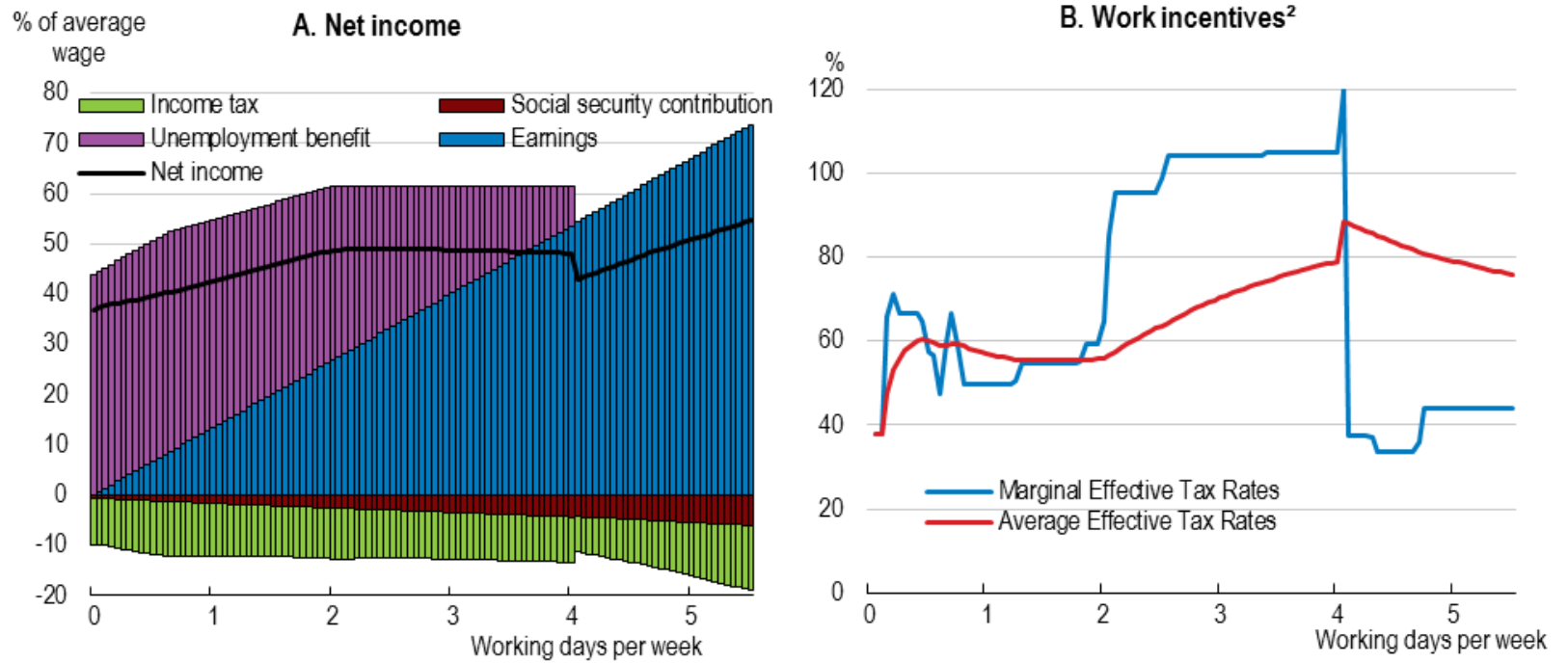

1. A single person entitled to unemployment insurance going into work in the initial phase of unemployment but following any waiting period, with hourly earnings pre- and post-unemployment of $67 \%$ of the national average wage. Means-tested benefits are allowed as top-ups to unemployment insurance.

2. Extreme positive rates have been capped at $120 \%$.

Source: Simulations with the OECD TaxBen model, in Pareliussen et al. (2018a).

The OECD TaxBen model embodies the rules governing the main working-age benefits of most OECD countries from 2001 to 2015 . This model is used below to describe the main features, strengths and weaknesses of the existing tax-benefit system compared to two possible directions of reform: a uniform benefit for all (universal basic income); and a uniform tapering rule for all existing benefits (universal 
credit). Estimates on how these scenarios affect inequality and public finances are obtained within the Finnish TUJA microsimulation framework, where tax- and benefit rules are linked to microdata (Pareliussen et al., 2018a).

Figure 6. Work does not always pay'

Incidence of unemployment traps ${ }^{1}$

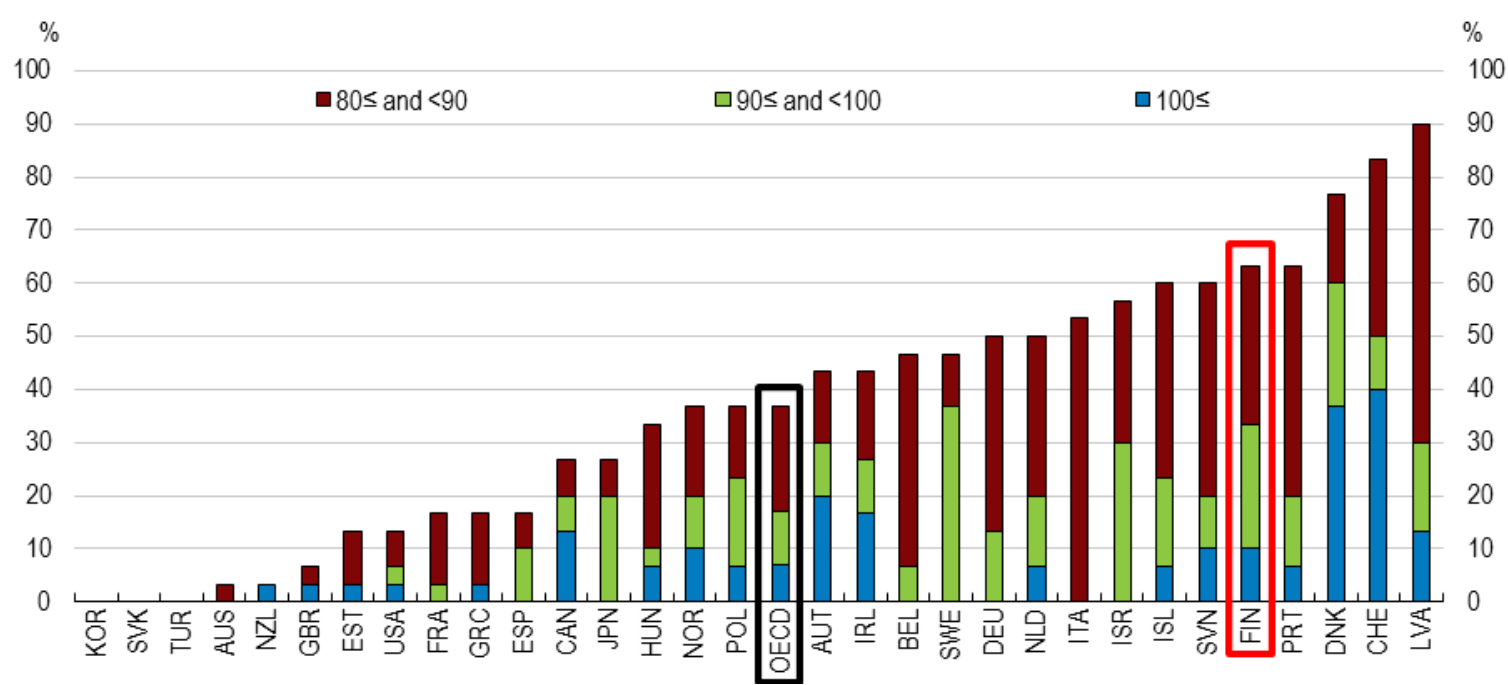

1. Incidence of an average effective tax rate within the indicated range for individuals transitioning from unemployment to full-time work in the initial phase of unemployment. A value of 100 means that all modelled individuals face inactivity traps. Zero means that none do. Unemployment insurance and means-tested top-ups are included. Average effective tax rates are modelled for six household types: single; single parent; couple, inactive spouse, no children; couple, inactive spouse, two children; couple, working spouse, no children, and; couple, working spouse, two children, and for five income levels: $33 \%, 50 \%, 67 \%, 100 \%$ and $150 \%$ of the national average wage. Households with children are assumed to have two children aged four and six.

Source: Simulations with the OECD TaxBen model, in Pareliussen et al. (2018a).

\section{Strengths and weaknesses of the current system}

Unemployment benefits, housing benefits, and social assistance fulfil related purposes and operate along the same dimensions, but have their particular sets of rules that are only partially harmonised. It is justified that different benefits have different eligibility criteria and formulas to calculate the initial benefit, as this reflects different needs and rights. Unemployment insurance depends on work history, active job search and participation in activation activities. The means-tested housing benefit depends on housing costs, subject to a ceiling determined by household size and local housing costs. Social assistance is a last-resort benefit aiming to raise living standards of all individuals to a minimum level, also accounting for family size and housing expenses. A homecare allowance is available for those who choose to forego public childcare and take care of their own children. Many municipalities also provide top-ups to the homecare allowance (Table 2.2; OECD, 2016b; Pareliussen et al., 2018a).

The analyses in this paper focus solely on work incentives and other policies and institutions directly affecting employment, but the benefit system can also have wider effects. For example, benefits covering housing costs may contribute to push up rents, which would in turn increase the level of benefits and thus reduce work incentives. Eerola and Lyytikäinen (2017) find no effects on rents from thresholds in the housing allowance, but the overall size of the housing allowance may nonetheless affect overall rent levels. Effects on rents can be expected to be more pronounced for the housing element of social assistance, as it covers full rents up to a threshold (the housing allowance only covers up to $80 \%$ of actual rents), but data to test for such effects has so far not been available.

Incentive issues arise primarily as a consequence of the speed at which benefits are scaled back (tapered) against earnings from work and income taxation. The different benefits apply different income definitions and different tapering rules. Unemployment insurance benefits are taxable and tapered on gross individual earnings. Social assistance and housing benefits provide top-ups to household income, and are not taxable. As in the other Nordics, the income tax is 
applied to individual income. Individual income taxation generally favours two-earner couples compared to taxation of household income, since second earners then benefit from tax allowances, tax credits and lower marginal taxes in progressive tax schedules. Income taxation in Finland consists of a flat-rate social security contribution, a flat-rate municipal income tax with a basic allowance and an allowance based on eamed income, a progressive central government income tax, an earned income tax credit and a child tax credit in addition to various other deductions covering special circumstances. Furthermore, the childcare fee for one to six year-old children attending public childcare is equivalent to an additional income tax with a floor and a ceiling but, contrary to regular income taxation, it is calculated on the basis of household income (Table 2.2; OECD, 2016b; Pareliussen et al., 2018a).

Table 2. Main working-age benefits and income taxation

\begin{tabular}{|c|c|c|c|c|}
\hline Benefit & Eligibility criteria & Initial amount & $\begin{array}{l}\text { Income/wealth } \\
\text { definition for tapering }\end{array}$ & Taxable \\
\hline $\begin{array}{l}\text { Labour market subsidy } \\
\text { (Työmarkkinatuki) }\end{array}$ & $\begin{array}{l}\text { Registered as } \\
\text { unemployed and } \\
\text { available for work or } \\
\text { activation policies }^{1}\end{array}$ & $\begin{array}{l}\text { A personal "basic } \\
\text { amount" and } \\
\text { supplements for } \\
\text { children }\end{array}$ & $\begin{array}{l}\text { Gross individual } \\
\text { earnings plus capital } \\
\text { income and parents' } \\
\text { income if living together }\end{array}$ & Yes \\
\hline $\begin{array}{l}\text { Basic unemployment } \\
\text { insurance } \\
\text { (Peruspäiväraha) }\end{array}$ & $\begin{array}{l}\text { As in the labour market } \\
\text { subsidy, plus } 26 \text { weeks } \\
\text { of work for the past } 28 \\
\text { months }^{1}\end{array}$ & $\begin{array}{l}\text { As in the labour market } \\
\text { subsidy }\end{array}$ & $\begin{array}{l}\text { Gross individual } \\
\text { earnings }\end{array}$ & Yes \\
\hline $\begin{array}{l}\text { Income-related } \\
\text { unemployment } \\
\text { insurance } \\
\text { (Ansiosidonnainen } \\
\text { työttömyyspäiväraha) }\end{array}$ & $\begin{array}{l}\text { As in basic } \\
\text { unemployment } \\
\text { insurance, plus } \\
\text { membership in } \\
\text { unemployment fund }^{1}\end{array}$ & $\begin{array}{l}\text { As in basic } \\
\text { unemployment } \\
\text { insurance plus a } \\
\text { percentage of pre- } \\
\text { unemployment income }\end{array}$ & $\begin{array}{l}\text { Gross individual } \\
\text { earnings }\end{array}$ & Yes \\
\hline $\begin{array}{l}\text { Housing allowance } \\
\text { (Yleinen asumistuki) }\end{array}$ & Low income & $\begin{array}{l}\text { Housing costs, family } \\
\text { size and composition, } \\
\text { geographical area }\end{array}$ & $\begin{array}{l}\text { Gross household } \\
\text { income including } \\
\text { taxable benefits }\end{array}$ & No \\
\hline $\begin{array}{l}\text { Social assistance } \\
\text { (Toimeentulotuki) }\end{array}$ & Low income & $\begin{array}{l}\text { Housing costs, family } \\
\text { size and composition, } \\
\text { geographical area, } \\
\text { childcare costs }\end{array}$ & $\begin{array}{l}\text { Net household income } \\
\text { after tax and benefits, } \\
\text { wealth }\end{array}$ & No \\
\hline $\begin{array}{l}\text { Homecare allowance } \\
\text { (Kotihoidontuki) }\end{array}$ & $\begin{array}{l}\text { Does not use public } \\
\text { childcare and has } \\
\text { children aged } 1-3\end{array}$ & $\begin{array}{l}\text { Number of children and } \\
\text { their age; municipal } \\
\text { supplement follows } \\
\text { local rules }\end{array}$ & $\begin{array}{l}\text { Gross household } \\
\text { income (only applies } \\
\text { for means-tested } \\
\text { supplement) }\end{array}$ & Yes \\
\hline
\end{tabular}

\begin{tabular}{llll}
$\begin{array}{l}\text { Childcare fee } \\
\text { (Päivähoitomaksu) }\end{array}$ & $\begin{array}{l}\text { Number of children } \\
\text { aged 1-6 in public } \\
\text { childcare }\end{array}$ & $\begin{array}{l}\text { Flat rate with floor and } \\
\text { ceiling }\end{array}$ & $\begin{array}{l}\text { Gross household } \\
\text { income }\end{array}$ \\
$\begin{array}{l}\text { Income taxation and } \\
\text { social security } \\
\text { contributions }\end{array}$ & & $\begin{array}{l}\text { Progressive tax } \\
\text { schedule }\end{array}$ & $\begin{array}{l}\text { Gross individual } \\
\text { income }\end{array}$ \\
\hline
\end{tabular}

1. Working hours may not exceed $80 \%$ of full-time work in the case of part-time unemployment benefits.

Source: OECD (2016b).

The monetary gain from taking up a job can be unattractive for many individuals on unemployment insurance, and is not even positive for all. The main disincentives originate in unemployment insurance tapering, even though housing benefits also matter (Figure 7, Panel A). Work incentives for those eligible to keep their benefit while working part-time are quite strong in Finland up to a certain point, with among the lowest average effective tax rates in the OECD. This is due to earned income tax credits, a EUR 300 monthly earnings disregard and relatively slow tapering of unemployment benefits (at a rate of 50\% of earnings). However, working a bit more than $40-50 \%$ of fulltime is discouraged by marginal effective tax rates slightly above $100 \%$ (Panel E), and working more than $80 \%$ of full time leads to the loss of the unemployment benefits, discouraging full-time work (Panel C). 
Individuals eligible for means-tested social assistance will also usually receive the means-tested housing benefit (Figure 7, Panel B). Social assistance is tapered at a rate of $80 \%$ of net income up to a

\section{Figure 7. Net income and work incentives in the current system 1}
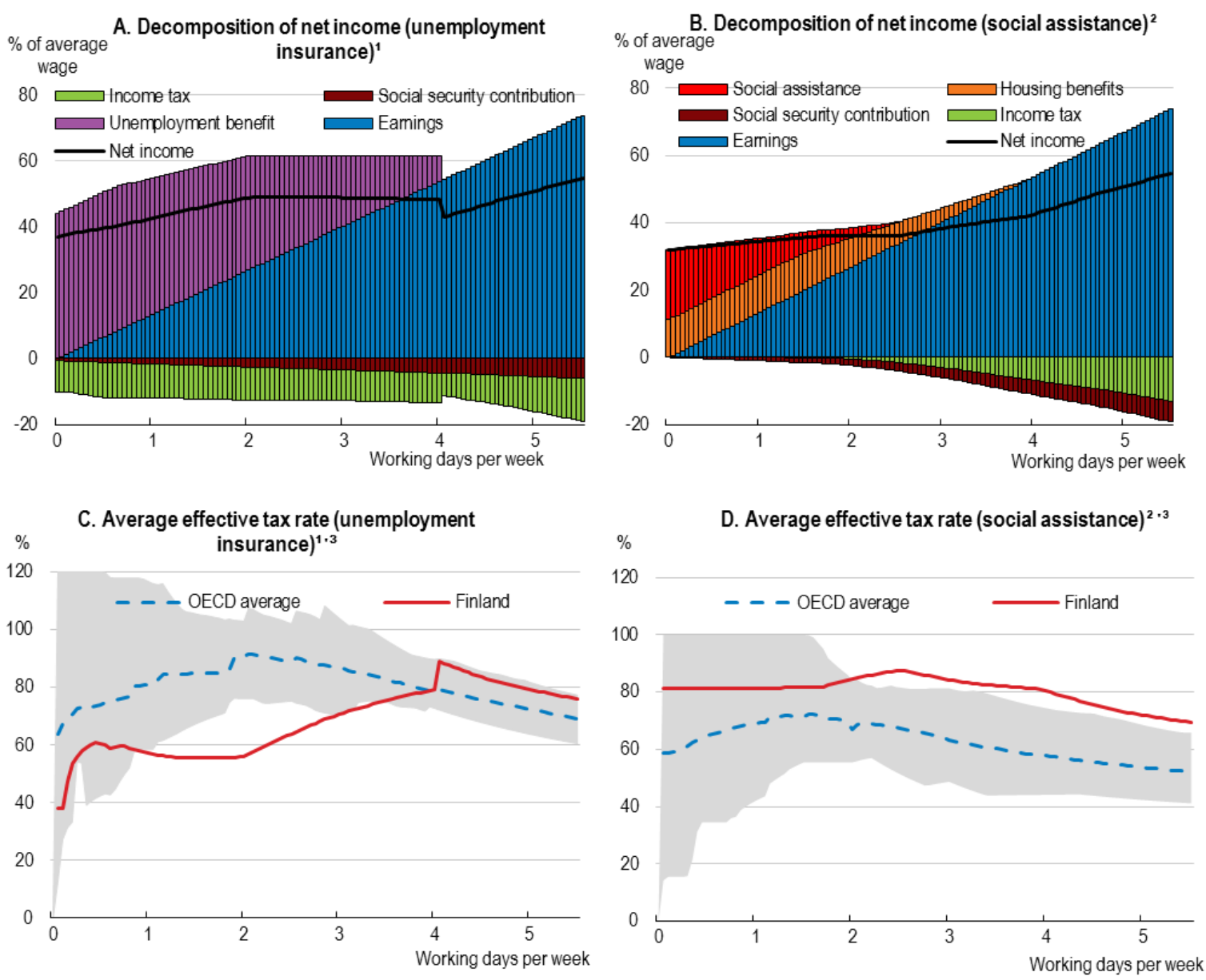

E. Marginal effective tax rate (unemployment

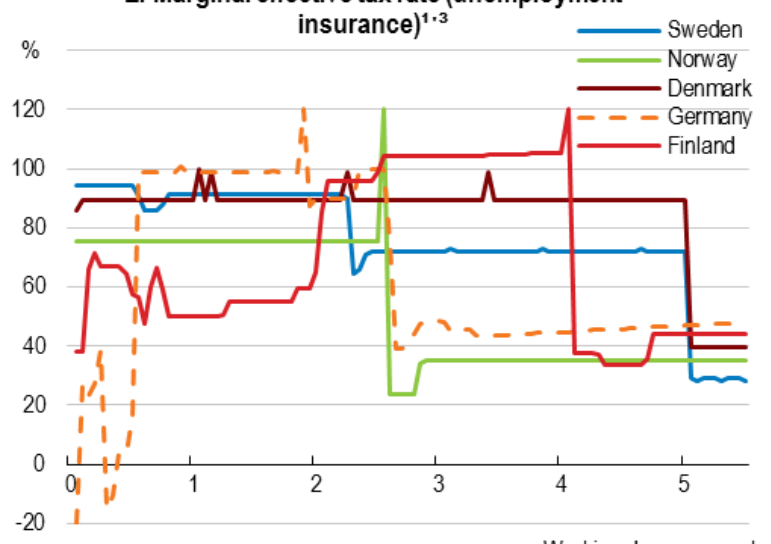

F. Marginal effective tax rate (social assistance) ${ }^{2 \cdot 3}$

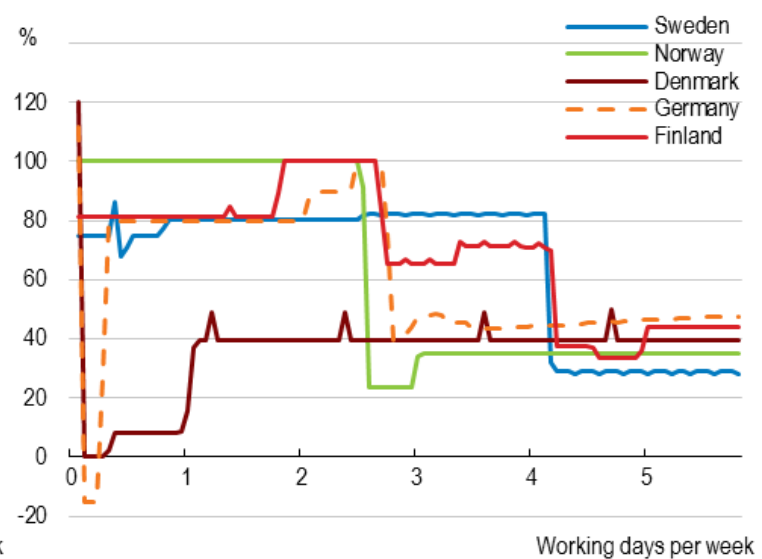

1. A single person entitled to unemployment insurance going into work, with hourly earnings pre- and post-unemployment of $67 \%$ of the national average wage in the initial phase of unemployment. Means-tested benefits are allowed as top-ups to unemployment insurance.

2. A single person not entitled to unemployment insurance going into work with hourly earnings of $67 \%$ of the national average wage.

3. Extreme positive rates have been capped at $120 \%$. Extreme negative rates have been capped at $-20 \%$. The shaded area denotes the range between the 25th and the 75th percentile in the OECD area.

Source: Simulations with the OECD TaxBen model, in Pareliussen et al. (2018a). 
threshold, after which it is reduced euro by euro. The housing benefit has relatively complex tapering rules translating to a taper rate of approximately $34 \%$ of gross household income, but since it is part of the income definition for social assistance, marginal effective tax rates for the two benefits combined never exceed 100\% (Panel, F). One-earner households (singles and couples with or without children) with moderate earnings prospects face average effective tax rates between 70 and $90 \%$ in most situations, which is high compared to the OECD average, but not unique (Panel D). However, second earners with children are eligible to receive the homecare allowance, and will also pay the childcare fee when entering work, resulting in an average effective tax rate well above $100 \%$ when working less than approximately $40 \%$ of full-time (Pareliussen et al., 2018a).

\section{Universal basic income: a uniform benefit for all}

A universal basic income has been proposed as an option to remove complexity and improve work incentives in Finland. The concept of a basic income is not new, and most OECD countries already include unconditional transfers to certain groups in the form of, for example, child benefits and basic old-age pensions. However, the idea of a benefit for the whole population, equal for all regardless of individual circumstances and other income, has gained renewed attention lately as a possible response to challenges facing traditional social protection systems, such as the rise of atypical forms of employment and risk of job losses due to automation, as well as imbalances between work, family and leisure. Incomplete coverage of insurance transfers leading to insufficient security for the poor in existing cash support is a further argument, although one with relatively little relevance for Finland, a country with low inequality and benefits effectively sheltering the poor (Figure 8). Furthermore, basic income has been put forward as a major simplification of existing benefit systems, and could improve work incentives significantly, since a basic income is not tapered against earnings. However, if existing spending on all working-age benefits was distributed to the same age group as a basic income with an equal amount to all, the benefit level would only constitute $26 \%$ of the relative poverty (50\% of median income) threshold. Financing a basic income at a meaningful level thus requires additional tax revenue, and heavier taxation of income will hence, at least partially, neutralise enhanced work incentives (OECD, 2017b).

\section{Figure 8. Existing cash support is targeted towards the poor in Finland'}

\section{3 or latest year available}

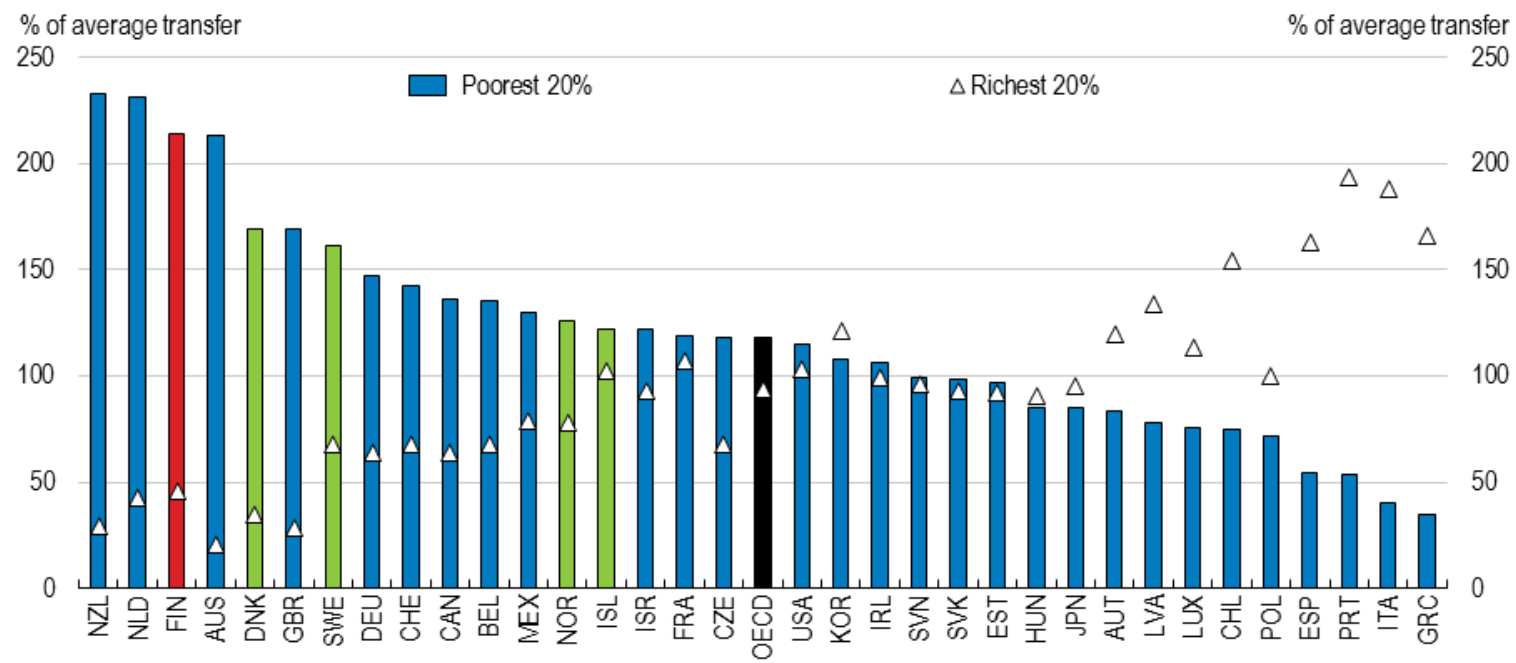

1. Public social cash transfers received by working-age individuals in low and high-income groups (equivalised disposable incomes). Age group 18-65, 18-62 in France.

Source: OECD (2017b). 
In Finland, a lively academic and political debate about the subject eventually led to the implementation of a two-year basic income trial, that started in January 2017. The experiment covers 2000 recipients of unemployment assistance, and converts the EUR 560 a month (before tax) unemployment assistance into an unconditional benefit in the sense that tapering and job search requirements are abolished for the individuals concerned. Income taxation and other benefits are kept unchanged, so that no participant loses out compared to the current system, contrary to what would happen if the scheme was implemented nationally and financed through taxation (Kela 2016; OECD, 2017b).

The basic income scenario presented here follows closely the scenario outlined in Browne and Immervoll (OECD, 2017b and Browne and Immervoll, 2017), with some exceptions (see Pareliussen et al., 2018a). The basic income applies to working-age individuals and is set at EUR 573 (486) per month before (after) tax, a level corresponding to social assistance for adults, with basic income for children derived from social assistance child supplements (EUR 237 before tax). The new benefit replaces unemployment, social assistance (except the housing element) and early retirement benefits, but disability benefits and cash support for housing are retained. Setting the basic income at a level that would fully remove the need for needs-tested housing related top-ups would imply crippling income taxation (Kela, 2016). All tax credits and allowances are removed to fund the reform. There is little rationale for a tax-free earnings allowance when everyone receives a minimum level of income. Furthermore, the zero bracket in the government income tax is abolished and all other brackets are shifted proportionally, which implies raising taxes significantly. The basic income is taxable, introducing some progressivity reflecting the income taxation schedule.

The basic income in this scenario undeniably reduces complexity in entitlement rules (Figure 9, Panel A). The cliff-edge loss of income associated with the loss of unemployment benefits when working more than $80 \%$ is also eliminated, enhancing incentives to work full-time for the unemployed. However, incentives to take on part-time jobs would be fairly weak, as the combination of heavier taxation on low incomes and tapering of housing benefits would imply high marginal effective tax rates on low earnings (Panel B), and average effective tax rates of around 90\% or above for individuals with moderate earnings potential working up to around $60 \%$ of full-time (Panel C). Second earners dependent on public childcare would, as in the current system, lose out compared to inactivity if working less than approximately $40 \%$ of full-time (Pareliussen et al., 2018a). 
Figure 9. Net income and work incentives in the basic income scenario'

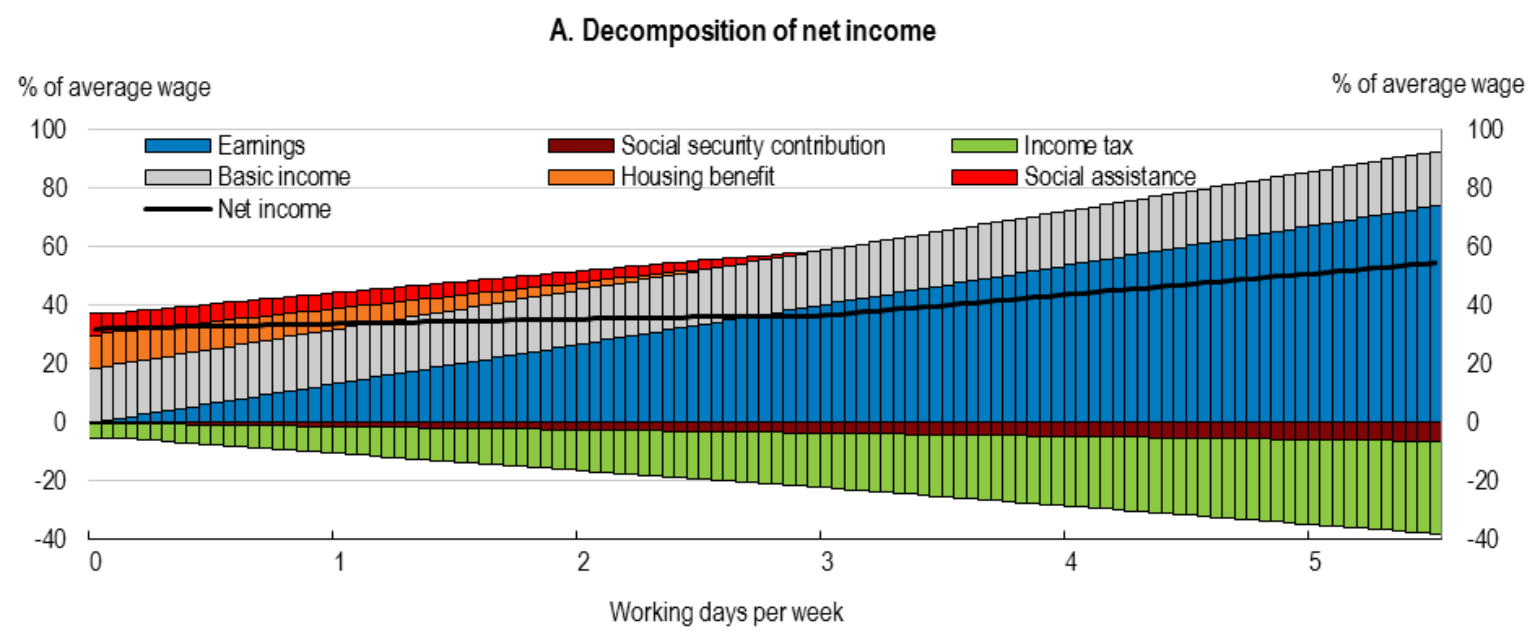

B. Average effective tax rate ${ }^{2}$

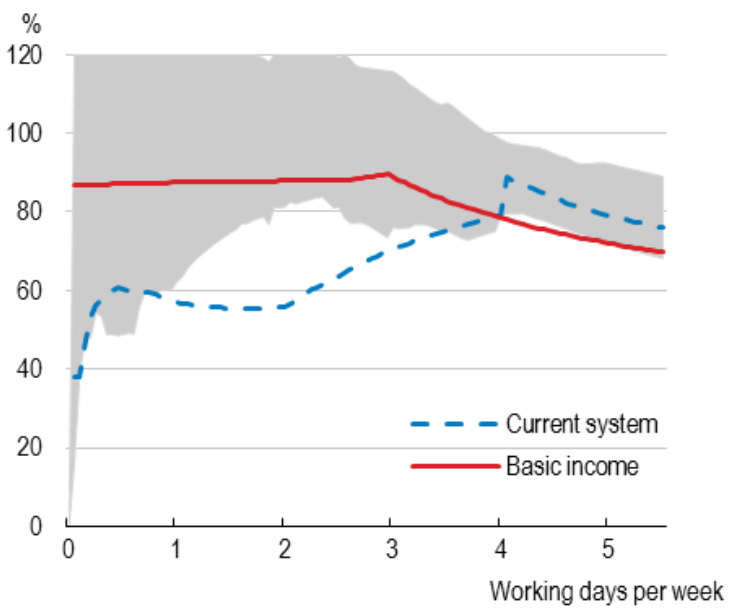

C. Marginal effective tax rate ${ }^{2}$

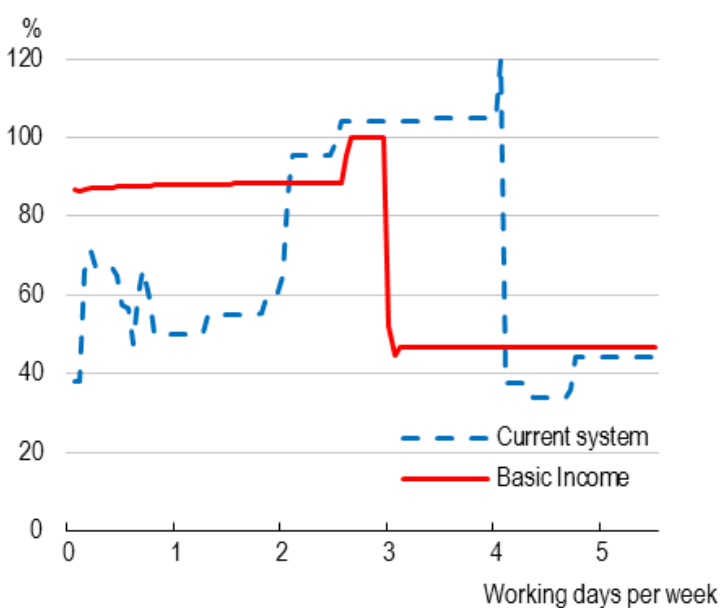

1. A single person going into work, with hourly earnings of $67 \%$ of the national average wage.

2. Extreme positive rates have been capped at $120 \%$. The shaded area denotes the range between the 25 th and the 75 th percentile in the OECD area.

Source: Simulations with the OECD TaxBen model, in Pareliussen et al. (2018a).

\section{Universal credit: a uniform tapering rule for all existing benefits}

A very different approach to reducing complexity and disincentives lies in harmonising tapering rules for the different working-age benefits. In practice, such an approach is equivalent to merging the benefits in question into one single benefit, and it requires centralisation of benefit administration and harmonisation of the tax treatment of benefits. If well-executed and linked to a functioning real-time income registry, such a benefit holds the potential to provide seamless transition from unemployment to work and adjustment to varying work hours. The most prominent example of this type of benefit system is found in the United Kingdom, where the process of rolling out a universal credit nationally is ongoing. This benefit reform has been criticised, but mostly on account of implementation issues and benefit cuts enacted in parallel with the reform (Box 2). 


\section{Box 2. Universal credit in the United Kingdom}

The universal credit welfare reform alters the structure of benefits, not the benefit levels, which by design are the same as before the reform for non-working individuals. The reform brings together six working-age benefits and tax credits related to social assistance, unemployment, housing and child support into one single benefit with one single taper rate. It is a monthly benefit, where the initial benefit is calculated on the basis of individual circumstances, and tapered against net real-time household income data. Policy aims were to simplify the benefit system from the viewpoint of users and administrators, to smooth the transition into work and to tackle poverty by increasing benefit take-up and make work pay regardless of the number of hours worked (Department for Work and Pensions, 2016).

The Department for Work and Pensions began rolling out the universal credit welfare reform in 2013. The roll-out has been gradual, starting with a limited number of employment offices and eligibility limited to single, childless and unemployed persons who did not own their own home. Full-scale roll-out in the North-West of England started mid-2014, where eligibility was subsequently extended to couples and families with children. The universal credit was rolled out nationwide between 2015 and 2016, but full service, digitally delivered and including all claimant groups, is only expected to be completed by 2022 . Earnings data are collected from the HM Revenue \& Custom's Real Time Information system, where employers and pension providers report earnings every time an employee is paid. Analyses of the initial roll-out show a positive labour market effect. Universal credit recipients were four percentage points more likely to be in work six months after the initial benefit claim than similar claimants under the old system (Department for Work and Pensions, 2016 and 2017).

Microsimulations have shown that the universal credit reform holds significant potential to boost incentives, notably for part-time work which is incentivised by earnings disregards, even though some alternative design choices could have further optimised work incentives. Second earners with children will see weaker incentives than before, the failure to include the Council Tax Reduction, a means-tested discount on the property tax, can weaken gains in work incentives somewhat, and means-testing against wealth can discourage savings (Department for Work and Pensions, 2011; IFS, 2016; Pareliussen, 2013). Furthermore, implementation has been delayed significantly compared to original plans, which were ambitious in timeframe and scope. Delivering the necessary IT infrastructure also proved more challenging than foreseen (National Audit office, 2013). Other relevant criticism relates to benefit cuts and an extension of the waiting period from 3 to 7 days which are not integral parts of the universal credit design, but as the cuts were enacted in parallel, the universal credit is often cited as the culprit of the resulting precariousness. However, initial difficulties have been overcome, and adjustments made along the way to allow for a continued roll-out of the universal credit as set out in the revised plan from 2016. Notable changes include reducing the taper rate from $65 \%$ to $63 \%$ in 2017 , and abolishing the 7 waiting days from January 2018.

The universal credit scenario merges unemployment related benefits, the housing allowance, social assistance and some child benefits into one single benefit with one single tapering rule. The calculation of the benefit amount for an individual out of work follows exactly the same rules as in the current system. An individual out of work should therefore receive (approximately) the same net income as in the current system. The universal credit is non-taxable and tapered on after-tax income, securing by design that the marginal effective tax rate never exceeds $100 \%$, and smoothing out marginal incentives for different earnings levels. Abolishing the homecare allowance and changing the childcare fee from the current income-tax structure to a lump-sum fee, offset by a new childcare supplement to the universal credit removes the current incentive traps for parents of children aged one to six. For simplicity, the scenario applies one single taper rate of $65 \%$ and no earnings disregard. Choosing a lower taper rate and/or a higher disregard would improve work incentives, but increase the cost of the benefit. The universal credit in the United Kingdom provides earnings disregards, varying by family type, with the explicit aim to improve work incentives for part-time workers (Pareliussen et al., 2018a).

Despite preserving the relatively complex rules of the current system governing eligibility and calculation of the initial amount, transparency and predictability would increase dramatically from the point of view of the benefit recipient. Once the eligibility and initial amount are confirmed by the public employment service, the pay-off from working or increasing work time is quite transparent (Figure 10, Panels A and B). 
Figure 10. Net income and work incentives in the universal credit scenario

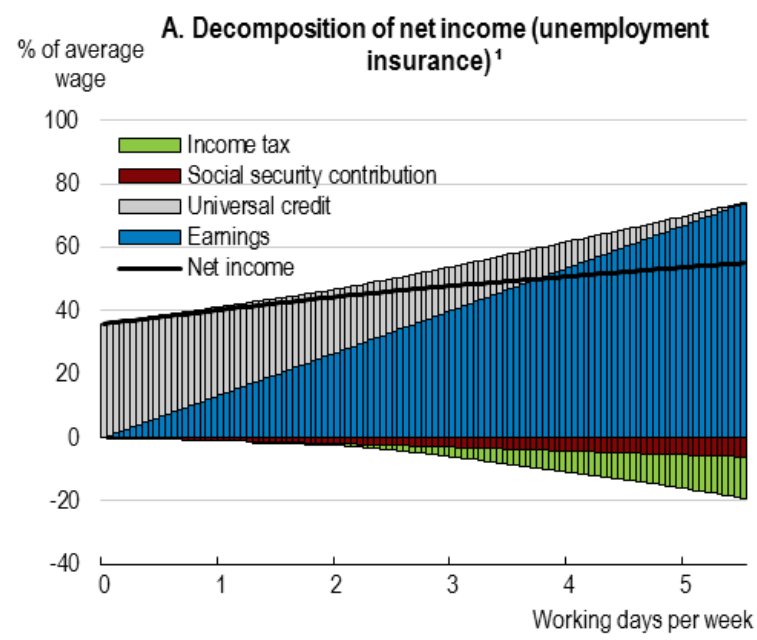

C. Average effective tax rate (unemployment insurance) ${ }^{1 \cdot 3}$

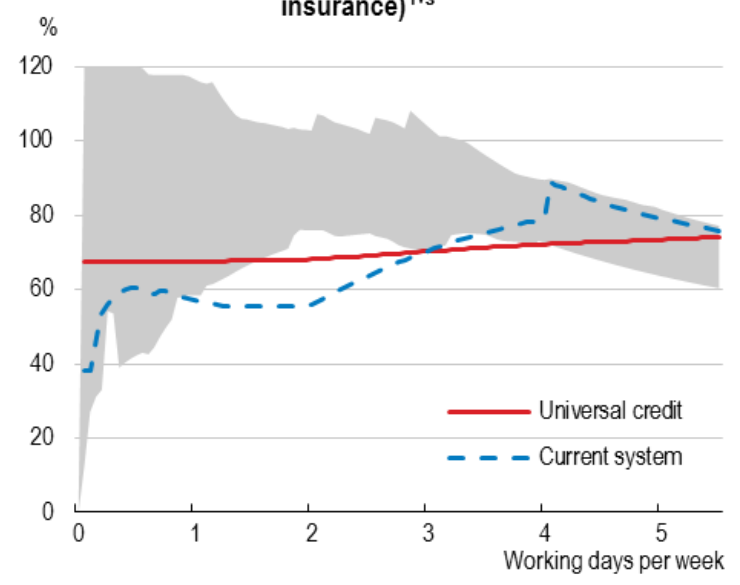

E. Marginal effective tax rate (unemployment insurance $)^{1,3}$

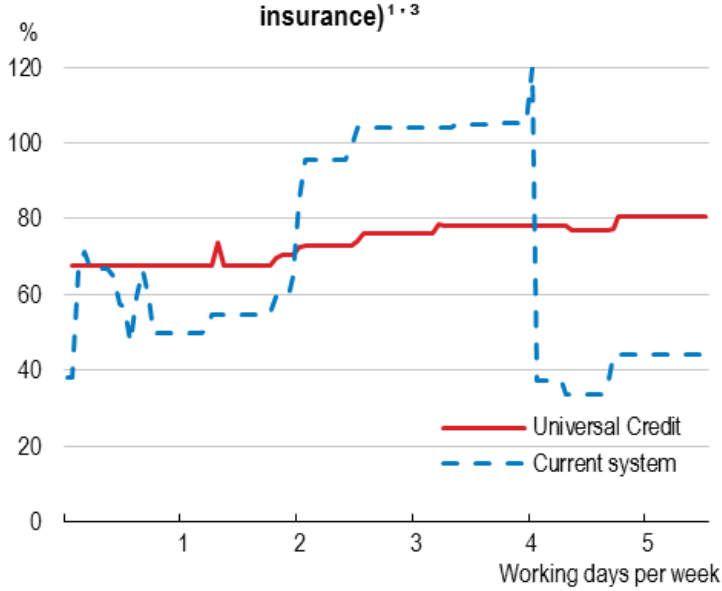

B. Decomposition of net income (social assistance) ${ }^{2}$ $\%$ of average

$$
\text { wage }
$$

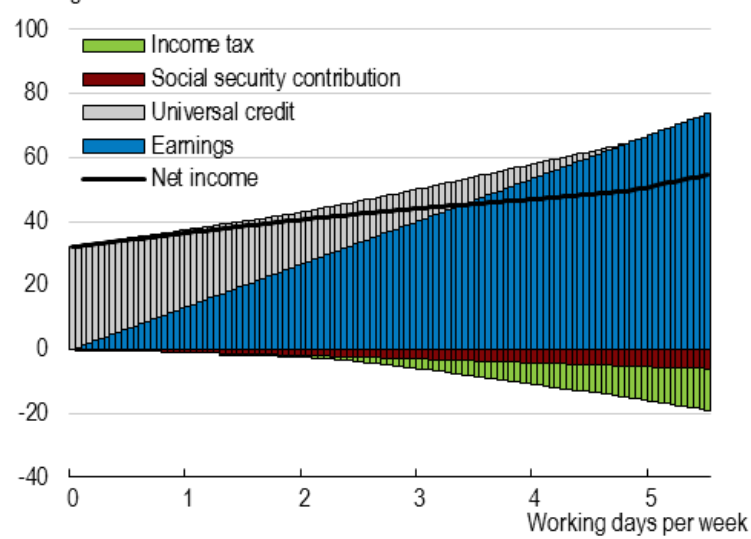

D. Average effective tax rate (social assistance) ${ }^{2 \cdot 3}$

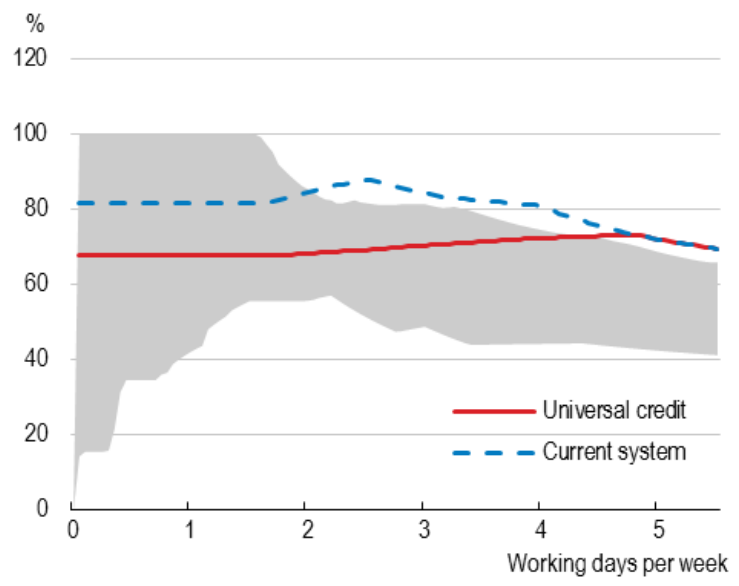

F. Marginal effective tax rate (social assistance) $)^{2 \cdot 3}$

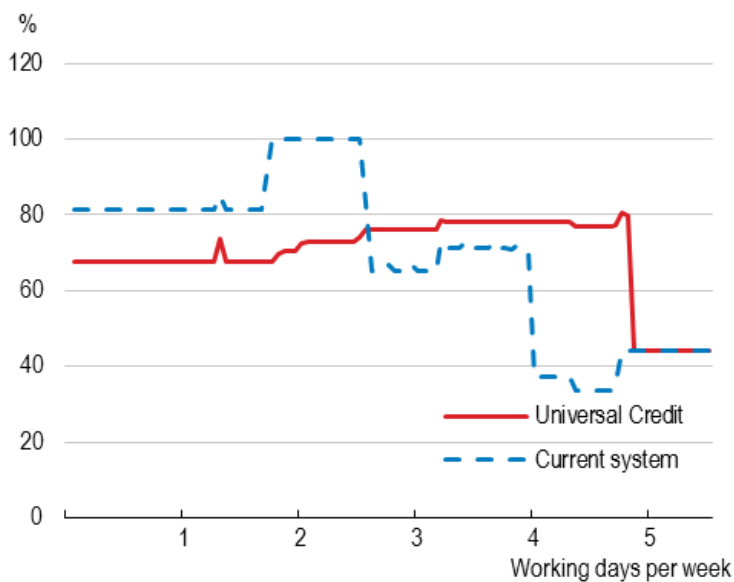

1. A single person entitled to unemployment insurance going into work, with hourly earnings pre- and post-unemployment of $67 \%$ of the national average wage. Means-tested benefits are allowed as top-ups to unemployment insurance.

2. A single person not entitled to unemployment insurance going into work with hourly earnings of $67 \%$ of the national average wage.

3. Extreme positive rates have been capped at $120 \%$. The shaded area denotes the range between the 25 th and the 75 th percentile in the OECD area.

Source: Simulations with the OECD TaxBen model, in Pareliussen et al. (2018a). 
More importantly, the pay-off will always be positive (Panels C and D). However, avoiding peaks in the marginal effective tax rate results in benefits being completely tapered off at higher earnings levels than before and it comes at the cost of inferior incentives to take on part-time jobs (up to around 40\%-50\% of full-time) compared to unemployment insurance recipients in the current system. Nonetheless, a longer interval of relatively high marginal effective tax rates is likely preferable to the "cliff-edge" benefit loss associated with unemployment insurance in the current system (Panels E and F). Individuals on social assistance have lower or equal average effective tax rates in the universal credit than in the current system.

\section{Comparing the scenarios: incentives, inclusiveness and affordability}

Full-time work is still the norm in Finland, and the most useful measure of work incentives for people on unemployment insurance, presumably relatively close to the labour market, may therefore be the average effective tax rate for full-time workers. However, many skills are job-specific, earnings potential deteriorates quickly following involuntary unemployment, shrinking regional job markets offer few attractive jobs, and the incidence of non-standard types of work also increases after displacement. A significant share of the unemployed may therefore not recoup the same salary level as before their unemployment spell (OECD, 2013). Deteriorating earnings potential can add to disincentives, because the benefit amount in the current unemployment insurance is calculated on the basis of previous earnings, while tapering is partially based on work hours.

In the current system an unemployed person with moderate pre-unemployment earnings and the possibility to go back to full-time work with $80 \%$ of previous earnings would face high average effective tax rates (84 to 118\%) when taking up employment, regardless of his or her family situation. This is mainly because unemployment benefit is cut off for those going back to working more than $80 \%$ of full-time. Even though this cut-off applies to all three versions of the unemployment benefit, it is more likely to be binding for recipients of income-related unemployment insurance than for those receiving more modest amounts in the basic unemployment insurance or the labour market subsidy, a benefit available to those who are not eligible for the other two versions, for example after long-term unemployment. Even with the same salary as in the old job, monetary incentives for an individual entitled to the earnings-related insurance would in many cases be weak, with 75 to $102 \%$ of earnings being taxed away, depending on family situation (Table 2.3). Work incentives are stronger under both the basic income and the universal

Table 3. Comparative average effective tax rates, income-related unemployment insurance Previous earnings $67 \%$ of national average wage ${ }^{1}$

\begin{tabular}{|c|c|c|c|c|c|c|}
\hline \multirow[b]{2}{*}{ Household type } & \multicolumn{3}{|c|}{$\begin{array}{l}\text { Going back to work full time with } 100 \% \text { of } \\
\text { previous earnings }\end{array}$} & \multicolumn{3}{|c|}{$\begin{array}{l}\text { Going back to work full time with } 80 \% \text { of } \\
\text { previous earnings }\end{array}$} \\
\hline & $\begin{array}{l}\text { Current } \\
\text { system }\end{array}$ & $\begin{array}{l}\text { Basic } \\
\text { income }\end{array}$ & $\begin{array}{l}\text { Universal } \\
\text { credit }\end{array}$ & $\begin{array}{l}\text { Current } \\
\text { system }\end{array}$ & $\begin{array}{l}\text { Basic } \\
\text { income }\end{array}$ & $\begin{array}{l}\text { Universal } \\
\text { credit }\end{array}$ \\
\hline Single & 79.1 & 72.0 & 73.4 & 89.4 & 78.3 & 72.2 \\
\hline Single parent & 97.7 & 86.2 & 73.4 & 99.5 & 91.4 & 72.2 \\
\hline $\begin{array}{l}\text { Single earner in } \\
\text { childless couple }\end{array}$ & 86.5 & 68.2 & 73.4 & 90.3 & 73.6 & 72.2 \\
\hline $\begin{array}{l}\text { Single earner in } \\
\text { couple with children }\end{array}$ & 88.3 & 74.4 & 73.4 & 93.8 & 81.3 & 72.2 \\
\hline $\begin{array}{l}\text { Second earner in } \\
\text { childless couple }\end{array}$ & 74.6 & 43.9 & 64.8 & 83.7 & 43.2 & 71.5 \\
\hline $\begin{array}{l}\text { Second earner in } \\
\text { couple with children }\end{array}$ & 102.0 & 66.1 & 73.4 & 118.0 & 71.0 & 72.2 \\
\hline
\end{tabular}

1. A person entitled to unemployment insurance. Means-tested benefits are allowed as top-ups to unemployment insurance. Households with children are assumed to have two children aged two and five. The person is going into work in the initial phase of unemployment but following any waiting period. This implies that individuals in the current system and the universal credit scenario are entitled to an increased income-related allowance, resulting in somewhat higher average effective tax rates than without this allowance. See Pareliussen et al. (2018a) for a detailed explanation and comparisons of incentives with and without the increased allowance.

Source: Simulations with the OECD TaxBen model, in Pareliussen et al. (2018a). 
credit. They would vary considerably with family type in the basic income, while they by design would be fairly uniform with the universal credit, never exceeding 73.4\%. Improved incentives under the basic income are partly a result of a considerably lower initial benefit level than in both the current system and the universal credit.

Simulations of work incentives of model households based on benefit rules, like the ones presented here, are useful to identify incentive issues and compare countries, but do not reveal how representative and relevant such stylised examples are. Kotamäki (2016) estimates that the incidence of average effective tax rates above $80 \%$ among unemployment insurance recipients is about $16 \%$. The highest concentration of disincentives is found among those receiving the earnings-related unemployment insurance, and disincentives hit parents in particular, with one third of single parents and one fifth of parents in couples facing average effective tax rates above $80 \%$.

Individuals not entitled to earnings-based unemployment insurance can typically be expected to have low earnings prospects and weak labour market attachment. Comparing the average effective tax rate for individuals with modest earnings prospects entitled to social assistance entering work shows that incentives in the basic income scenario are inferior or equivalent to the current system for half-time workers. This is due to the higher marginal tax rates necessary to fund the benefit, combined with the tapering of housingrelated benefits. The universal credit on the other hand, displays equivalent or better incentives for all household types because of a lower taper rate. For full-time workers, different work incentives between the basic income and the current system reflect that a basic income is more generous towards couples, while the combination of higher income taxation and tapering of the housing-related benefit reduces incentives for single-headed households. Tax rates in the universal credit scenario never exceed $73.4 \%$, a considerable improvement compared to the current system (Table 2.4).

Table 4. Comparative average effective tax rates, social assistance and housing benefit

Hourly wage equal to $67 \%$ of the national average wage

\begin{tabular}{lcccccc}
\hline & \multicolumn{3}{c}{ Half time } & \multicolumn{3}{c}{ Full time } \\
\hline Household type & $\begin{array}{c}\text { Current } \\
\text { system }\end{array}$ & $\begin{array}{c}\text { Basic } \\
\text { income }\end{array}$ & $\begin{array}{c}\text { Universal } \\
\text { credit }\end{array}$ & $\begin{array}{c}\text { Current } \\
\text { system }\end{array}$ & $\begin{array}{c}\text { Basic } \\
\text { income }\end{array}$ & $\begin{array}{c}\text { Universal } \\
\text { credit }\end{array}$ \\
$\begin{array}{l}\text { Single } \\
\text { Single parent }\end{array}$ & 87.6 & 87.9 & 69.1 & 72.0 & 72.0 & 72.0 \\
$\begin{array}{l}\text { Single earner in } \\
\text { childless couple }\end{array}$ & 67.6 & 92.5 & 69.1 & 77.1 & 86.2 & 73.4 \\
$\begin{array}{l}\text { Single earner in couple } \\
\text { with children }\end{array}$ & 87.6 & 87.9 & 69.1 & 86.5 & 68.2 & 73.4 \\
$\begin{array}{l}\text { Second earner in } \\
\text { childless couple }\end{array}$ & 87.6 & 87.9 & 69.1 & 80.6 & 74.4 & 73.4 \\
$\begin{array}{l}\text { Second earner in } \\
\text { couple with children }{ }^{1}\end{array}$ & 11.6 & 41.9 & 11.6 & 24.0 & 43.9 & 24.0 \\
\hline
\end{tabular}

1. Households with children are assumed to have two children aged two and five.

Source: Simulations with the OECD TaxBen model, in Pareliussen et al. (2018a).

Behavioural effects on employment and income under the basic income cannot be quantitatively estimated in a static microsimulation framework, but are likely to be significant under such an extensive reform. Work incentives would be more favourable for some because of less means-testing and lower benefit levels, and less favourable for others because of heavier income taxation. The absence of activation requirements would likely contribute to reducing employment, when seen in isolation. In contrast, the universal credit would resolve a number of incentive issues, while keeping existing activation policies in place. The overall employment effect of this scenario should hence be positive.

The static effects of the basic income scenario would strengthen the budget balance by EUR 4.6bn, or $2 \%$ of GDP. The cost of the basic income (17bn) is more than offset by increased taxation (13.1bn), and 
reduced net expenditure, notably on social assistance ( $2.5 \mathrm{bn})$, unemployment benefits ( $2.1 \mathrm{bn})$, early pensions (1.2bn) and the child benefit ( $1 \mathrm{bn})$. In the universal credit scenario, the budget balance strengthens by EUR 0.8bn. However, this scenario is modelled with tapering of the universal credit on family income, as it is methodologically difficult to calculate the individual part of the universal credit with annual microdata. The fiscal savings are thus likely overstated compared to a scenario with individual rights to an unemployment insurance supplement (Pareliussen et al., 2018a).

Fiscally neutral scenarios are constructed to isolate the redistribution effects of potential reforms. Reducing the marginal income tax by 4 percentage points makes the basic income scenario close to fiscally neutral. Such a reform would change the income distribution significantly, with losses in the bottom four income deciles and small gains in the top six. Incomes in the lowest deciles are reduced most strongly by abolishing social assistance and unemployment benefits, but abolishing early pensions, student grants and income tax allowances and credits also affect low incomes disproportionally. The basic income offsets these income losses to an extent, but not completely. The modified income tax schedule, along with abolishing child benefits, sickness benefits and parental leave reduces middle incomes disproportionally (Figure 11, Panel A). A fiscally neutral universal credit scenario is constructed by lowering the universal credit taper rate to $38 \%$. The average income in the two lowest deciles increases, likely as a result of higher benefit take-up and slower tapering of social assistance. Falling incomes in the middle of the distribution are mainly related to the loss of unemployment benefits. These losses would be lower with an unemployment insurance supplement tapered on individual income (Panel B).

Figure 11. A basic income would reduce incomes in the bottom of the distribution

Changing disposable incomes under benefit reform scenarios ${ }^{1}$

A. Basic income

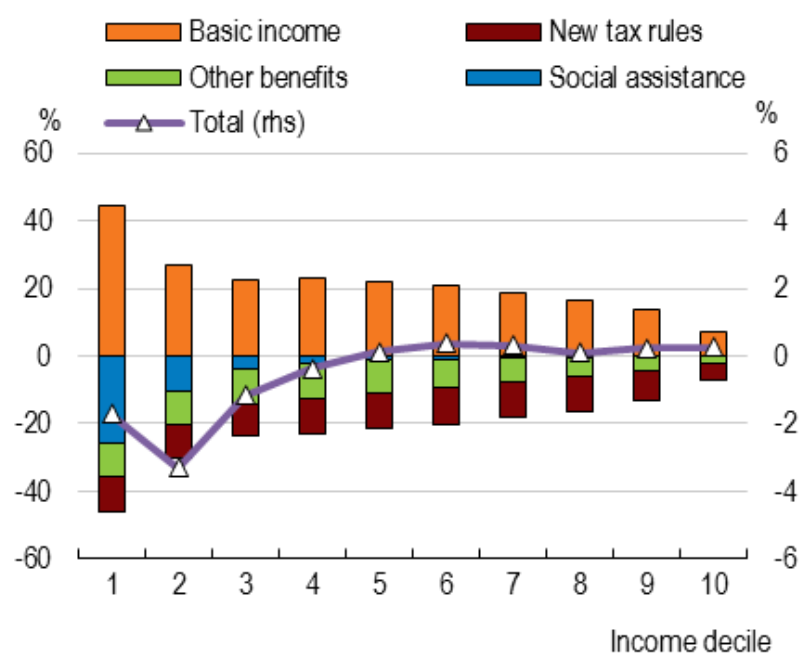

B. Universal credit

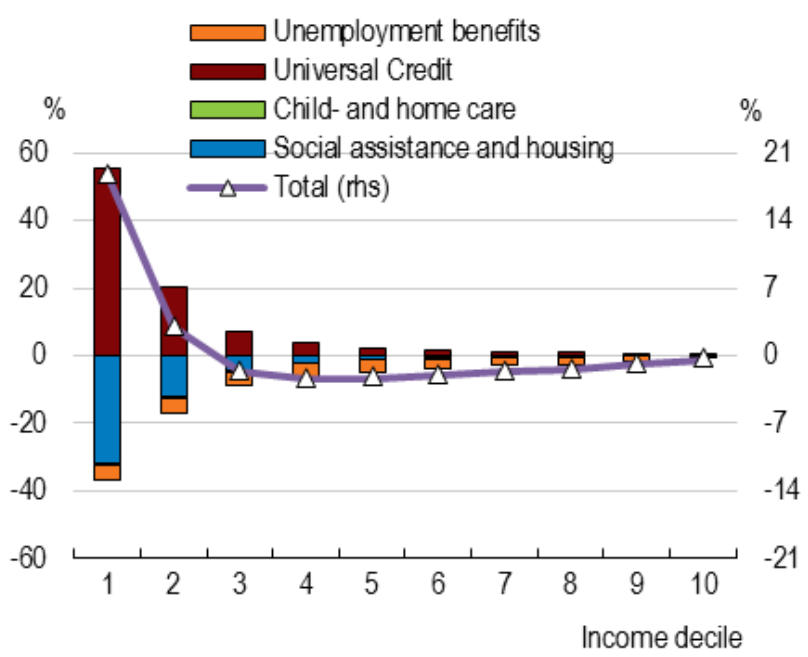

1. Percentage change compared to pre-reform disposable income within each income decile.

Source: Simulations with the TUJA model, in Pareliussen et al. (2018a).

Overall, in the fiscally neutral basic income scenario the Gini coefficient increases by approximately 0.4 percentage points. The poverty rate rises from $11.4 \%$ to $14.1 \%$, and of the 150000 persons falling below the poverty line, 30000 are children, and 50000 early pensioners. Furthermore, the structure of the benefit system changes, substantially affecting most individual incomes. Only around $6 \%$ of the population will see their incomes unchanged, a third of the population will see income gains of over $10 \%$, and a fifth will lose more than 10\%. Many of the people who would be poor after a basic income reform would not be those who are poor today: $3.6 \%$ of the working-age population would fall into poverty as a consequence of 
this reform, while $0.8 \%$ would move out of poverty (Figure 12). This significant redistribution of income arises because the universal individual benefit in this scenario is more generous towards couples than singles than the current targeted system, the income-based unemployment insurance is abolished, benefit take-up increases and taxation changes (Figure 13).

Figure 12. A basic income scenario would alter the income distribution

Share of individuals in working-age households
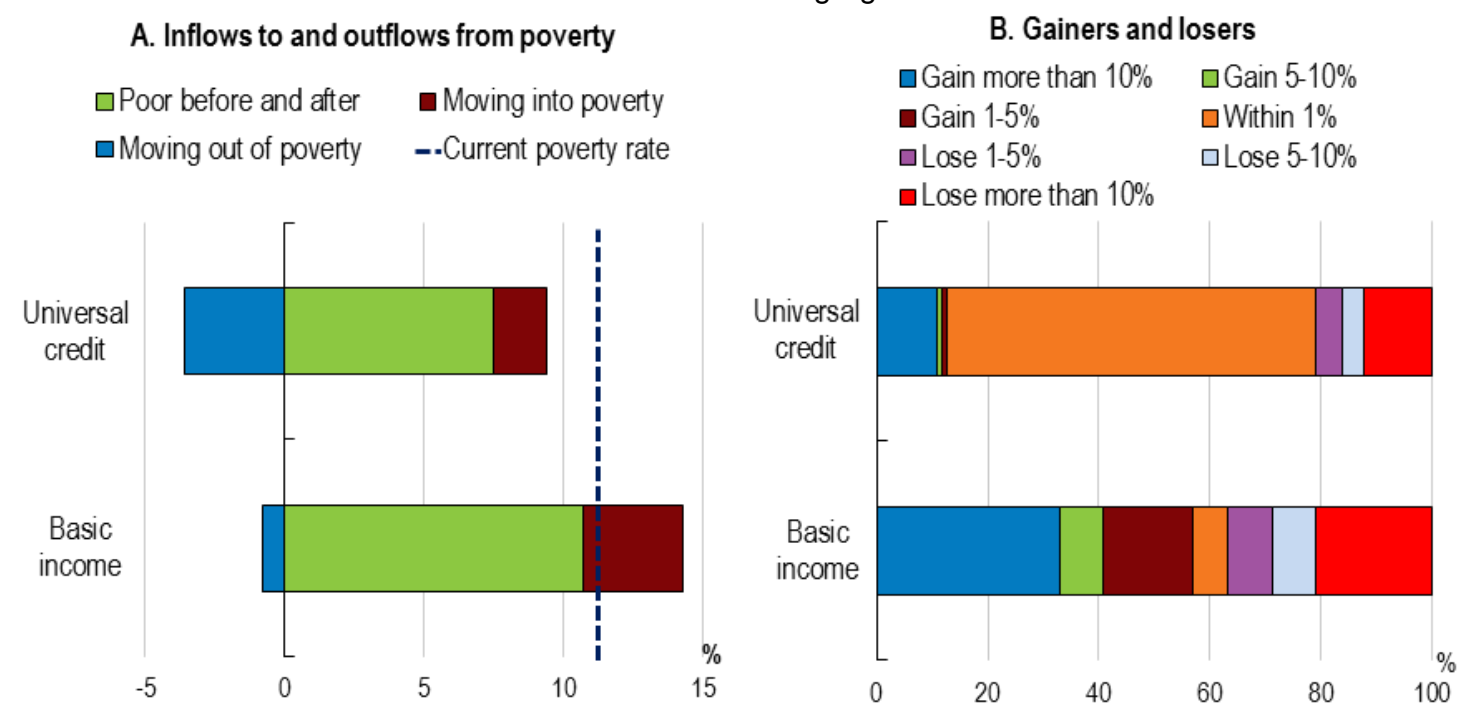

Source: Simulations with the TUJA model, in Pareliussen et al. (2018a).

In contrast, in the universal credit scenario, the Gini coefficient falls by 0.9 percentage points, and 90 000 people exit poverty, thereby reducing the poverty rate by 1.7 percentage points to $9.7 \%$. In general, fewer people see their incomes affected in this scenario, and households losing over $10 \%$ of their income mostly do so because unemployment insurance is tapered on household- rather than individual income. Large gains for some individuals, notably in the first decile, are probably partly a result of increased takeup, but likely also reflect less steep benefit tapering in the universal credit scenario (Figure 13).

It should be noted that these results depend on the assumptions underlying the scenarios. The basic income for example is designed as one uniform benefit for all, in line with what is commonly associated with the term. Other lump-sum benefit structures, more targeted towards individuals in need, would likely perform better along the inequality dimension. 
Figure 13. Net household income in the different scenarios ${ }^{1}$
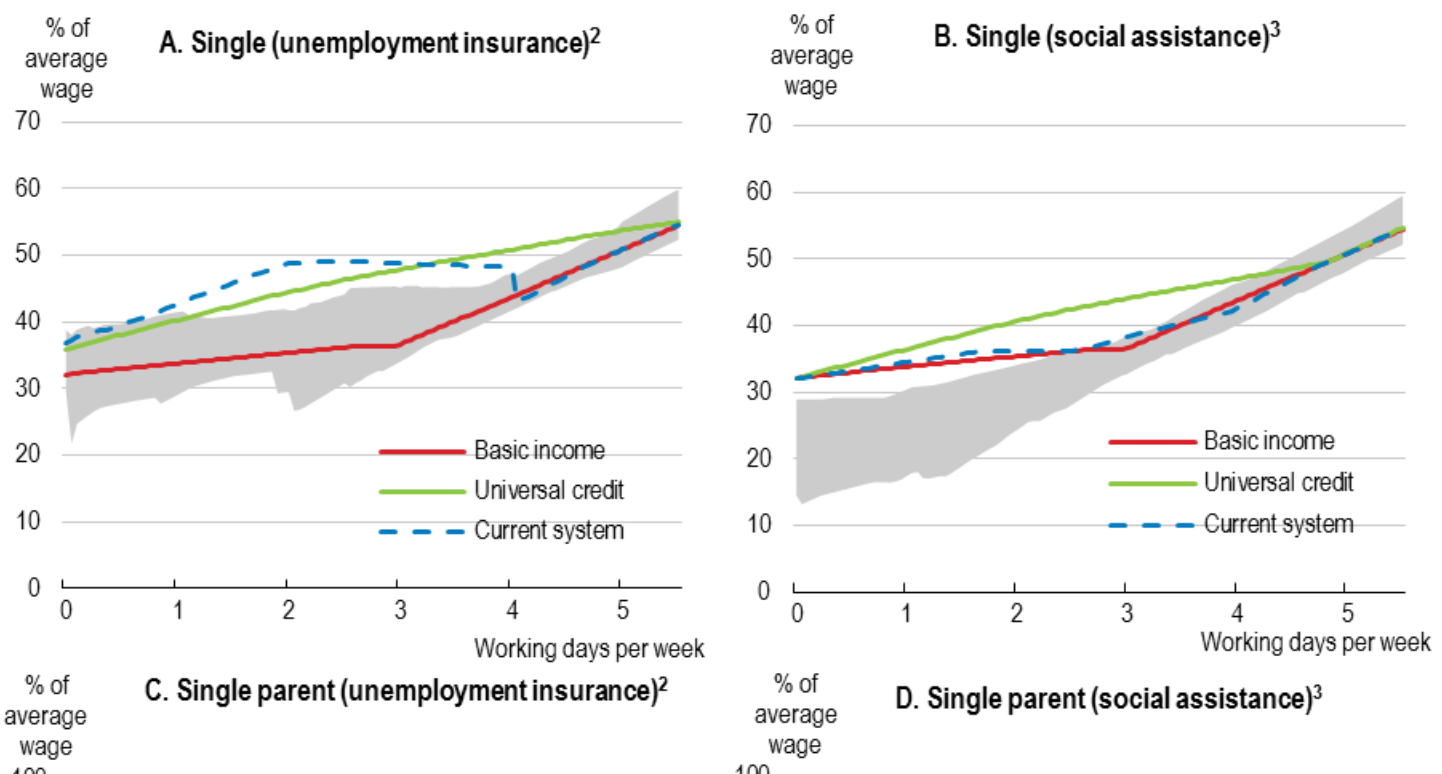

average

wage

wage

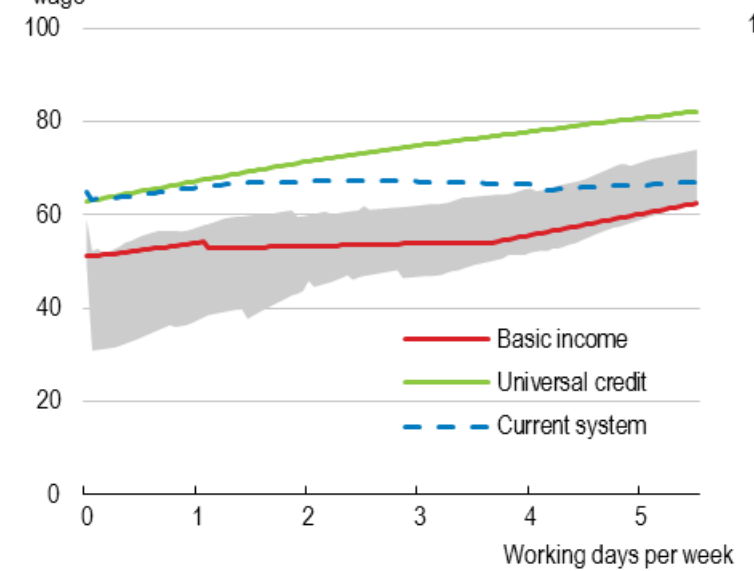

100

80

60
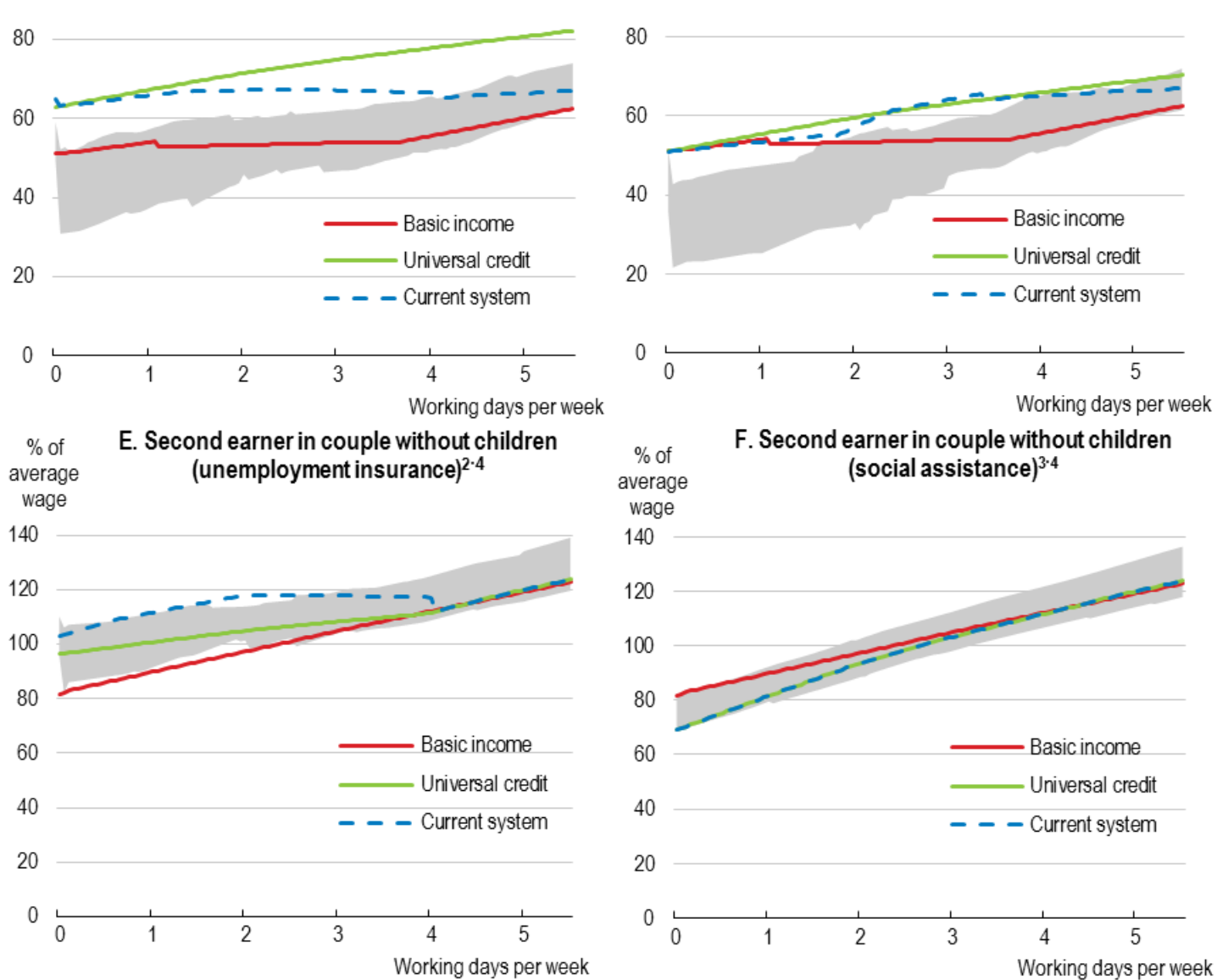

1. The shaded area denotes the range between the 25 th and the 75 th percentile in the OECD area.

2. A person entitled to unemployment insurance going into work, with hourly earnings pre- and post-unemployment of $67 \%$ of the national average wage. Means-tested benefits are allowed as top-ups to unemployment insurance.

3. A person not entitled to unemployment insurance going into work with hourly earnings of $67 \%$ of the national average wage.

4. The primary earner earns the national average wage.

Source: Simulations with the OECD TaxBen model, in Pareliussen et al. (2018a). 


\section{Towards robust work incentives and protection for all}

The simulations above illustrate in the case of Finland how different models of tax-transfer systems perform in the balancing act between incentives, protection and affordability. They also illustrate some of the problems with corner solutions: full means-testing and "cliff-edges", with sudden benefit reductions or loss of benefit eligibility can undermine work incentives. A universal basic income at a level that does not imply crippling income taxation, bearing in mind that there are limits to taxation of capital, consumption and externalities ( OECD Economic Survey of Finland, 2018), is not generous enough to protect individuals in vulnerable life situations. Even when retaining means-tested top-ups, a basic income will imply that the current targeting of benefits changes drastically, resulting in a major redistribution of income, presumably at odds with social preferences. A basic income may also increase poverty as illustrated in the basic income scenario, although the exact redistribution effects depend on the design of the basic income scheme.

In contrast, moving towards coordinated benefit tapering as illustrated in the universal credit scenario can alleviate complexity and strengthen work incentives without social reducing protection. However, benefit reform does not need to be a revolution as described in the two scenarios above, and many of the weaknesses in the current system can be mitigated without replacing the full benefit system. Indeed, experience from the implementation of major welfare reforms, such as the Universal credit in the United Kingdom (Box 2) and the Norwegian NAV reform (Fimreite et al., 2012) illustrate that major reorganisations can come with significant costs. Implementation should hence be stepwise, building on the existing institutional context, and important technical building blocks should be fully operational and welltested before full roll-out.

\section{Ensuring smooth transitions between work and benefits}

Finland has already moved towards better coordination of benefits, by centralising benefit administration in Kela. This is an important first step towards better harmonisation. Furthermore, the housing benefit went through a major simplification in 2015. In the long term, harmonising the tax treatment and income definitions of working-age benefits by making all either taxable or non-taxable and calculating them on either gross or after-tax income could pave the way for restructuring benefits into their core functions, with coordinated tapering as described in the universal credit scenario. To fill the functions of the current benefit system, such a system would consist of a personal basic amount, a child supplement, a housing supplement and an unemployment insurance supplement.

In the short to medium term, bureaucratic traps could be fought by investing in better software for the public employment service (PES), which would enable caseworkers to better analyse individual circumstances and give more precise advice about the consequences of taking up work. Taking this one step further, delegating decision power to PES staff, at least for relatively straightforward cases, could be considered. A combination of timely decisions and a change in rules extending rights to benefits without tapering for a limited period of time after taking up work would go a long way in resolving this issue and reinforcing incentives to enter work. The basic unemployment benefit can be used as a mobility and wage subsidy as of 2017, which is a step in this direction (European Commission, 2017). Furthermore, the government plans to extend unemployment benefits for four months to the unemployed who start an entrepreneurial activity (Ministry of Finance, 2017a).

The planned implementation of a real-time income registry and its link to benefit payments in 2020 holds the potential to provide truly seamless transitions between work and benefits. It also opens up the possibility for on-line applications that could accurately assess the consequences of freelance work, taking up regular work or increasing efforts, based on individual real-time circumstances. The real-time registry 
could hence promote transparency and predictability, even if the underlying benefit rules are complex. However, the development of integrated IT systems for the public sector is often challenging for multiple reasons, including diverging stakeholder goals, the need to balance different user needs, technological integration and compatibility issues, as well as constraining regulations and requirement specifications (Moe and Päivärinta, 2013). Privacy issues and IT security also need to be taken into account. A transition to real-time coordination of earnings and benefits should hence only be made when the real-time income registry is fully operational and tested.

\section{Improving work incentives for prime-age workers}

The cliff-edge loss of unemployment insurance benefits when working more than $80 \%$ of full time strongly discourages full-time work, and should be abolished. Replacing the $80 \%$ limit by other mechanisms would avoid that the unemployment insurance becomes a general labour market subsidy. A time limit for receiving unemployment insurance while working close to full-time is one possible solution. Somewhat higher tapering on low incomes combined with a lower initial benefit level could make the $80 \%$ limit obsolete, and is hence an alternative, but positive effects should be weighed against reduced incentives to take on part-time jobs and a weakened insurance function of the unemployment benefit.

Incentives are also a function of the time dimension. Outflows from unemployment increase drastically towards the end of eligibility for the earnings-related unemployment insurance. About half of those who exit just before earnings-related unemployment insurance expiry find a new job or are recalled to their old job. The other half enters job-placement programmes or exit the unemployment insurance altogether (Figure 14). The spike in outflows at exhaustion is a useful illustration, but with limited impact on overall unemployment, as only a minor fraction of recipients stay unemployed until benefit exhaustion.

Figure 14. Exit rates spike immediately before unemployment benefit expiry ${ }^{1}$

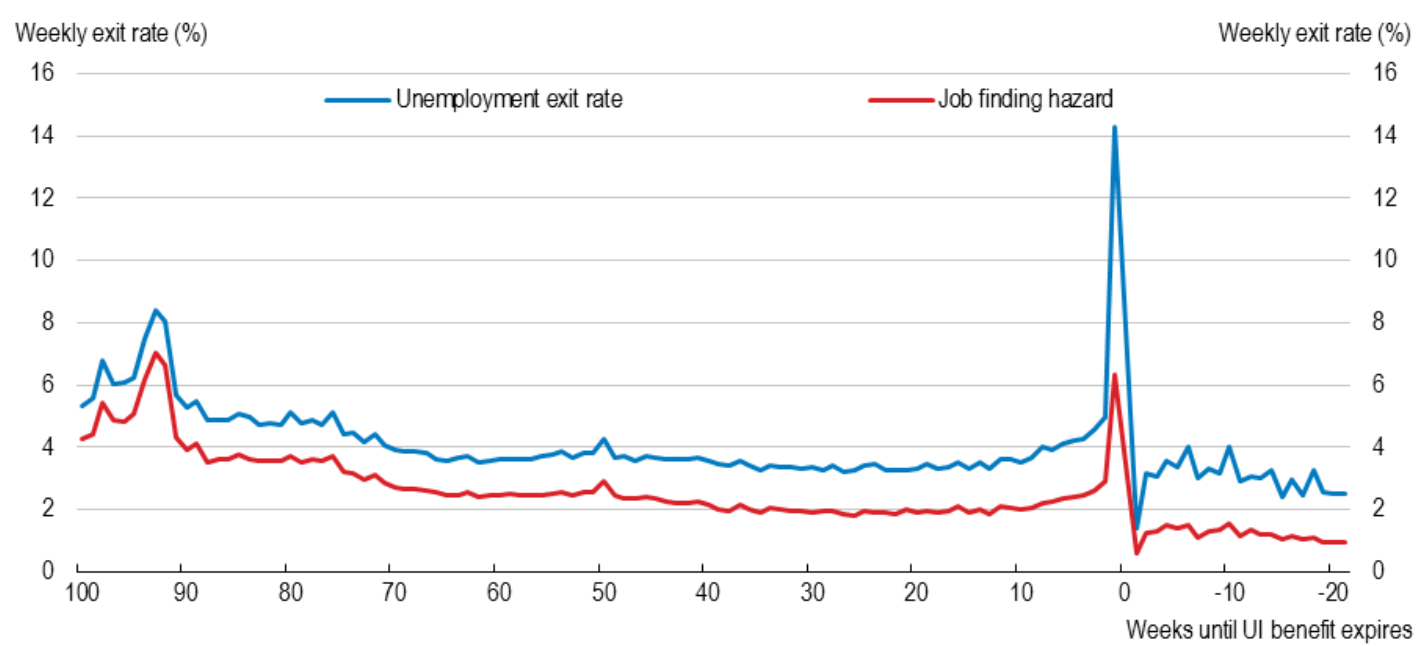

1. Unemployment and job finding rates as a function of time-to-exhaustion for all those entitled to unemployment insurance.

Source: Kyyrä et al (2017a).

However, reducing unemployment benefit duration also increases job-finding rates earlier in the unemployment spell, and is therefore effective in reducing unemployment, while preserving meaningful insurance. The duration of the earnings-related unemployment benefit was cut by 100 days from 500 to 400 days (300 days for careers shorter than three years) in January 2017. This reduction is estimated to reduce average unemployment duration by $10 \%$, and to significantly increase employment. Furthermore, the reform could result in fiscal savings of more than EUR 100m. Increasing inequality from lower benefit payments is expected to be neutralised by increasing employment (Kyyrä, et al., 2017a and b; Ministry of Finance, 2017b; Kotamäki et al., 2017). Seeking to trigger similar threshold effects earlier in the unemployment spell, the government introduced a new activity requirement from January 2018. Those 
who do not work or participate in activation activities for at least 18 hours during each three-month period following unemployment will get their unemployment insurance reduced by $4.5 \%$ in the following three-month period (Ministry of Finance, 2017a).

Social assistance is tapered at a rate of first $80 \%$, then $100 \%$ of net income. Lowering the tapering rate would improve incentives somewhat, but would lead to interactions with the tapering of the housing benefit, which is part of the social assistance income definition. Marginal effective tax rates would therefore remain high unless the two benefits are merged or tapered in sequence. Merging the two benefits into one should be possible, as social assistance already contains a housing element, and both benefits are means-tested on family income and administered by Kela. However, their income definitions would need to be fully harmonised and legal issues concerning the role of social assistance as a last-resort benefit would need to be resolved. Moving away from the current model where the full rent is covered by social assistance towards a model where tenants have an incentive to search for housing with lower rents should be considered.

\section{Making work pay for parents}

A combined restructuring of the homecare allowance and the childcare fee would transform work incentives for parents of children aged 1-6 years completely and likely reduce the average duration of leave following childbirth, in line with previous OECD recommendations (OECD Economic Survey of Finland, 2016). The government reduced the childcare fee for families with two or more children in public childcare by approximately $20 \%$ (depending on individual circumstances) from 2017. Although a significant step in the right direction, resolving the current incentive issues requires a more profound restructuring.

The homecare allowance is equivalent to a direct subsidy to stay out of the workforce for parents who depend on public (municipal) childcare, and strongly disincentivises second earners from taking on part-time work. It consists of a basic amount per child and a means-tested supplement, and many municipalities provide additional top-ups to reduce demand for childcare. In 2015, the employment gap between women aged 20-49 with young children and women in the same age group without children was 15.7 percentage points (European Commission, 2017). The homecare allowance may not be combined with unemployment benefits. Furthermore, inactive single parents will normally not face adverse incentives from the allowance, since it is counted as income in calculating social assistance and housing benefits. It therefore mainly affects second earners, notably women with low education and skills resulting in modest earnings prospects (Figure 15). One option is to abolish the homecare allowance entirely.

Figure 15. Employment rate by skills and age ${ }^{1}$

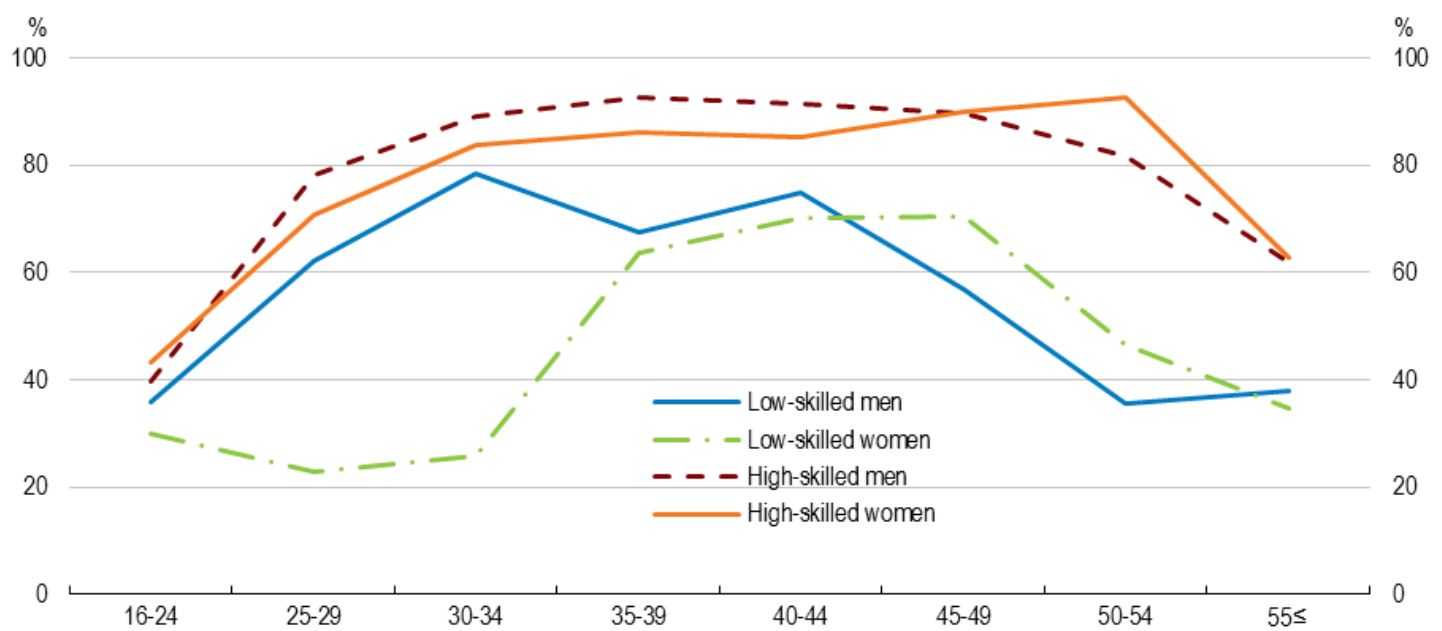

1. Low skills are defined as literacy proficiency at or below PIAAC level 2. High skills are defined as PIAAC level 3 or above. Data were collected in 2012.

Source: OECD Survey of Adult Skills, 2012. 
Alternatively, using the savings from removing the homecare allowance to increase the basic parental leave amount would largely remove disincentives, while partially compensating losers. Increasing the flexibility to take out a lower parental leave benefit to three years would preserve free choice to stay at home with young children as in the current system, but without subsidising labour market exit.

The childcare fee is only payable above an income threshold, after which it increases gradually with household income up to a ceiling. Second earners will normally be well above the threshold as a consequence of the spouse's income. Entering work, even at low hours, will in this case entail significant childcare payments. A solution to significantly strengthen incentives for second earners would be to individualise the current fee by calculating it on the basis of the lowest-earning spouses' income. Alternatively, the current structure could be replaced by a lump-sum fee combined with an offsetting, individualised childcare benefit, as in the universal credit scenario (Figure 16, Panel A). In the latter case, tapering would need to be coordinated with other benefits to avoid creating new disincentives for single parents (Panel B). Removing disincentives for mothers would increase the demand for public childcare, and hence increase childcare expenditure. However, changing the childcare fee structure as described above would create some room to increase the fee with limited additional disincentives. The cost of individualising the existing fee could be limited somewhat by removing the floor in the fee structure for second earners.

Figure 16. Improving incentives for second earners ${ }^{1}$
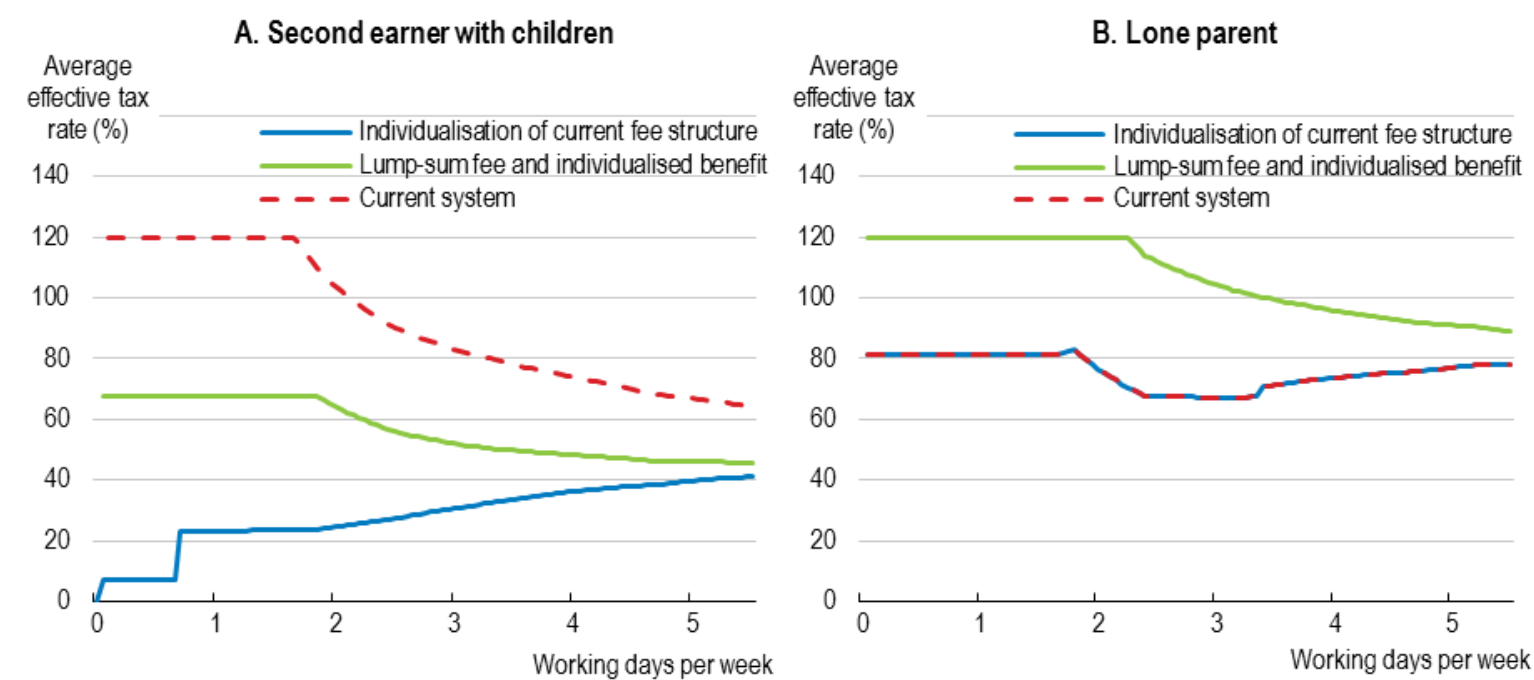

1. The homecare allowance is abolished in both scenarios. The "lump-sum fee and individualised benefit" scenario replaces the childcare fee structure by a lump-sum fee combined with a childcare benefit tapered off by $65 \%$ of after-tax income. Tapering is not coordinated with tapering of other benefits. In couples, the benefit is individualised and tapered against the income of the spouse with the lowest earnings. The "Individualisation of current fee structure" scenario keeps the current childcare fee structure, but the income test to set the level of the childcare fee is applied to the spouse with the lowest earnings. The modelled individual is not entitled to unemployment insurance, and he or she is going into work with hourly earnings of $67 \%$ of the national average wage.

Source: Simulations with the OECD TaxBen model, in Pareliussen et al. (2018a).

\section{Narrowing the unemployment tunnel for older workers}

As in many other European countries, longer entitlement periods to unemployment insurance benefits are provided for older unemployed. In Finland, those aged above 61 on the day their unemployment insurance expires qualify for extended unemployment benefits until the statutory pension age (the "unemployment tunnel"). The unemployment tunnel increases inflows to unemployment substantially, as employers tend to target dismissals to eligible individuals, and because eligible workers may voluntarily choose to use the tunnel. Furthermore, the tunnel reduces outflows from unemployment, as extended eligibility to unemployment benefits discourages job-search. The tunnel is often used as a bridge to 
retirement, in practice extending benefit eligibility indefinitely. Indeed, the incidence of unemployment peaks at the age of 62, and the unemployed aged 62 or more tend not to search for jobs (Kyyrä and Pesola, 2017; OECD Economic Survey of Finland, 2016).

A pension reform taking effect in 2017 raises the statutory pension age gradually from 63 to 65 years before linking it to life expectancy from 2030 onwards, and increases the age threshold for the unemployment tunnel from 61 to 62 years. Increasing the pension age has put the pension system on a sustainable trajectory, but ageing costs are still expected to show up in unemployment, health and longterm care expenditures. The reform is expected to raise the average retirement age by one year, but only increase time in employment by five months due to higher unemployment. Time in employment would only increase by three months if the age threshold for the unemployment tunnel was not raised (Economic Policy Council, 2015). A previous two-year increase in the age threshold increased employment within the affected age group by seven months (a 9\% increase) (Figure 17) and resulted in a substantial increase in individual net income, as well as EUR 500 million in fiscal savings for each birth cohort over a 10-year period. Disability and sickness benefits were not affected by the reform, and no effects were found on mortality and the spouse's labour force participation (Kyyrä and Pesola, 2017). Even though a positive employment effect can be expected from raising the threshold in the latest pension reform, the distance between the statutory pension age and the unemployment tunnel age threshold widens, and changes to pension accrual rules considerably increase incentives to opt for the unemployment tunnel. Given the substantial positive effects on employment and public finances from increasing the age threshold, together with the absence of negative side-effects, the unemployment tunnel threshold should as a minimum increase in line with the statutory pension age. Furthermore, disability pensions should be restricted to medical conditions only, the eligibility criteria for the new years-of service pension should be kept strict and selective measures to allow early retirement should be avoided (OECD Economic Survey of Finland, 2016; European Commission, 2017).

Figure 17. Shortening the unemployment tunnel increases employment substantially ${ }^{1}$

Months employed in 2004-13 by birth week

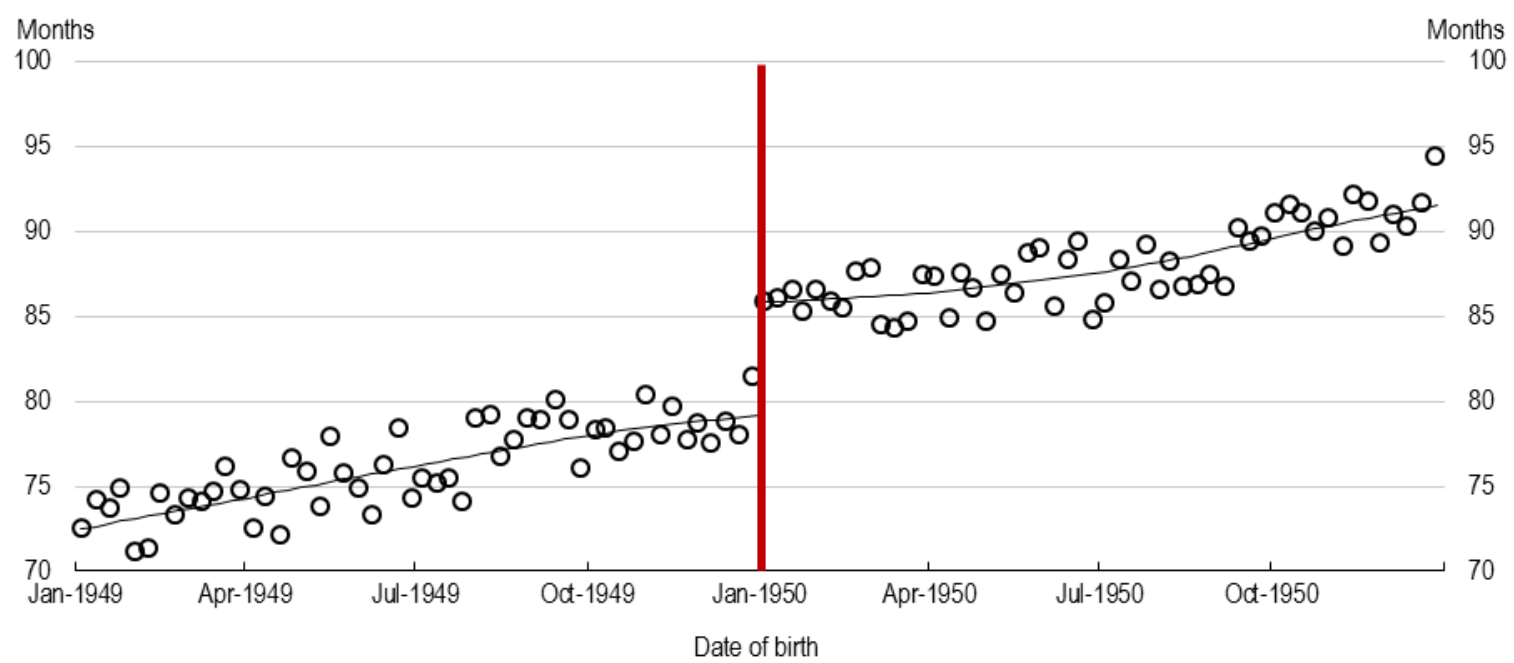

1. The unemployment tunnel age threshold was increased from 55 to 57 years in 2005 , only applicable to individuals born after 1949 . Source: Kyyrä and Pesola (2017).

\section{Flanking policies to boost matching, supply and demand for labour}

The employment impact of a given policy reform, such as improving work incentives, depends on the institutional context, and tends to be greater the more employment-friendly the overall institutional framework is (Bassanini and Duval, 2009). Notwithstanding some room for improvement, the institutional context in Finland is generally favourable. 


\section{Education and life-long learning}

Labour market outcomes depend crucially on education and skills (OECD, 2015). In Finland and the other Nordic countries, a compressed wage distribution leads to relatively low skill premiums. The return to education is hence to a large extent reflected in higher and more stable employment (Pareliussen et al., 2018b).

Finland is renowned for its excellence and equity in compulsory education, and still ranks among the top countries in the OECD Programme for International Student Assessment (PISA), despite a downward trend in PISA results since 2006 and some skill shortages (OECD, 2016c; OECD, 2017c). Furthermore, skill use at work is among the highest in the OECD (OECD, 2016d). Some areas of concern remain, apart from overall declining results. Boys are increasingly falling behind girls, notably in reading, the drop-out rate from secondary education is high, and enrolment in early childhood education is low, a feature which should be seen in the context of work incentives for single parents and second earners (OECD Economic Survey of Finland, 2016). Steps are taken to further improve compulsory education, notably through "phenomenon-based learning", which consists of multidisciplinary collaborative projects resembling reallife problem solving more closely.

Around $40 \%$ of upper secondary students follow the three-year vocational track. The $O E C D$ Economic Survey of Finland 2016 pointed to the need to strengthen foundation skills within vocational education and consolidating the high number of programmes and formal vocational qualifications in order to improve graduates' adaptability to a changing world of work. Engaging employers in the apprenticeship system can also improve the alignment between the supply and demand of skills (OECD/ILO, 2017). A new core curriculum came into force in the second half of 2016, putting more emphasis on basic skills, such as reading and mathematics. The programme structure has also been reformed, with fewer and broader qualifications. The strict distinction between universities and universities of applied science (formerly termed polytechnics) has been removed, the use of university entrance exams will be strictly limited from 2020 and a series of mergers in the university sector is underway. This consolidation of the tertiary education sector, together with a move towards modular qualifications in universities and upper secondary education hold the potential to improve people's flexibility to re-train and adapt their qualifications to the changing needs of the labour market.

\section{Active labour market policies}

The Finnish public employment service has undergone major changes in the past few years, from being highly decentralised to the current centralised structure, with the aim to harmonise services and improve efficiency in delivery (OECD, 2016e). A centralised structure aligns incentives with responsibilities, since the bulk of the cost of unemployment is borne by the central government. However, as of 2020, 18 new regions are to take over the responsibility for employment services, which they will purchase from public, private and third-sector providers. This reform represents a leap into uncharted territory, and its success depends on a number of factors, including the development of the necessary IT infrastructure and appropriate procurement models and systems to ensure quality in provision, foster competition and avoid cream-skimming from service providers. Furthermore, funding for the new regions will not be earmarked to different purposes. Hence, there is a risk that overruns in healthcare or social expenditures could crowd out funding for employment services. A shift towards payments to providers based on employment outcomes, as signalled in the 2018 budget proposal, has shown some merit in initial trials (OECD, 2016e), and a similar model targeted towards immigrants is being trialled, where returns to investors in a "social impact bond" is tied to participants gaining employment. Such trials provide useful experience in preparation for the 2020 regional reform. 
The unemployment surge following the 2008 financial crisis, along with budget cuts, have put the employment service under strain. The number of unemployed per caseworker more than doubled from 2008, despite a slight improvement in 2016 (Figure 18). Although spending on active labour market policies is high, notably on labour market training, total public expenditure on employment service administration and counselling is low relative to unemployment benefit spending. The new requirement to work or participate in activation activities at least 18 hours every three months, the new job-search requirement and recent tightening of the obligation to accept job offers or participate in activation schemes can improve outcomes, together with long-standing practices of job referrals and individual employment plans as well as cooperation with employers (OECD, 2016f). However, these policies require close followup, coaching and monitoring to be effective, in line with the government's decision to have more frequent meetings with caseworkers from the beginning of 2017. Funding for the employment service was increased in 2017, and shifting some funding from relatively expensive activation programmes towards more and earlier face-to-face contact with a jobseeker could be considered. Policies towards older and low-skilled displaced jobseekers who seem to have less access to ALMPs compared to other groups and who find it more difficult to return to employment should also be strengthened (OECD, 2016e; OECD, 2015; Ministry of Finance, 2017b; European Commission, 2017; OECD Economic Survey of Finland, 2016).

Figure 18. Rising unemployment and budget cuts have put the employment service under strain

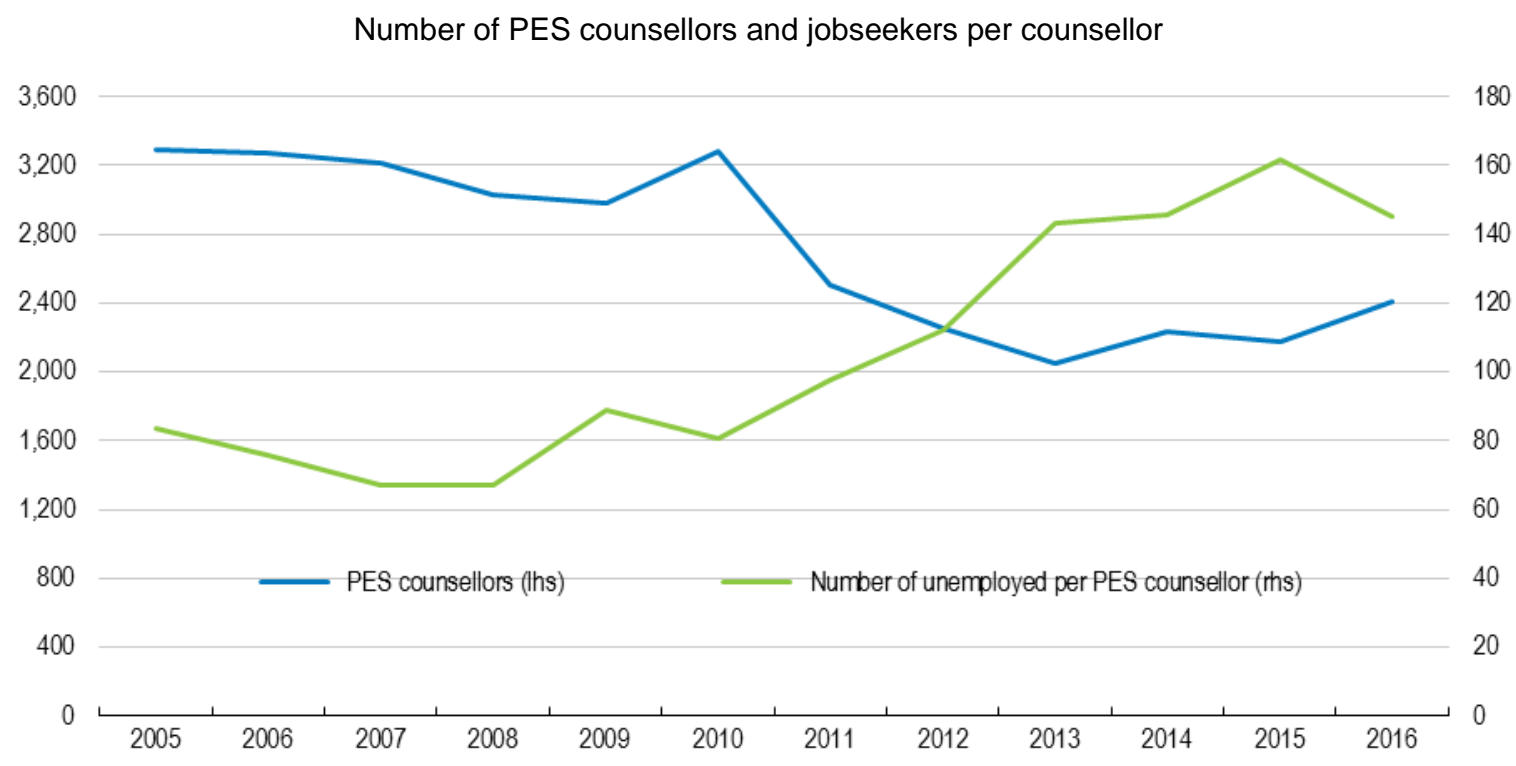

Source: Ministry of Employment and Industry of Finland.

A further challenge is to adapt activation policies to non-standard workers, and also seize the opportunities from new types of employment. A first step is to provide the same quality of activation to those who are out of work, but not entitled to unemployment benefits. Finland already requires social assistance recipients to participate in activation. Furthermore, services targeted at disadvantaged groups need not necessarily be limited to those out of work. Providing "in-work progression" services, for example offering training and mentoring, could help individuals in non-standard or unstable employment. Attendance could be voluntary, or it could be mandatory in cases where individuals receive housing, social assistance or unemployment benefits as earnings top-ups (OECD, 2015; OECD, 2017a).

Even though employment outcomes from several activation policies in Finland seem positive, it is not possible to establish causality between measures and outcomes (OECD, 2016e). Building on its strong tradition of performing small-scale trials before rolling out new policy initiatives, Finland could emulate several countries which have set up special "behavioural economics" teams responsible for performing controlled experiments to improve the effectiveness of policies (Box 3). 


\section{Box 3. Examples of controlled experiments in activation policies}

The use of behavioural sciences to guide policy has become commonplace in many countries. Case studies from the United Kingdom and Singapore illustrate how controlled experiments can contribute to improving design, implementation, and effectiveness of policy.

United Kingdom: Interventions encouraging people to search for work were implemented gradually in Jobcentre Plus in 2013-14. The order in which the centres made the switch was randomised, creating a treatment group and control group. The interventions consisted of:

- Simplification: The first appointment in Jobcentre Plus was streamlined, with job-seekers building a relationship with their advisor and discussing their job search from the start.

- Planning aid: A commitment pack specifying where, when and how job-seekers were going to complete their job search activities was developed in cooperation between job-seekers and caseworkers. The new commitment pack asked job-seekers to plan their job search and then carry it out, rather than simply requiring that job-seekers document what they had done retrospectively.

The result of the interventions showed a 1.7 percentage point increase in the proportion of people exiting benefits in 13 weeks relative to the business-as-usual model. This suggests that simplifying processes, focusing on job search rather than meeting minimum requirements, and planning aids were successful at supporting job-seekers to find employment.

Singapore: A study identified four key barriers to re-employment. Job-seekers tended to be passive in the job search process and rely on caseworkers to look out for and arrange job interviews for them. Commitment and turnout for training sessions and interviews arranged by their caseworker were low. Job goals and wage expectations were unrealistic. Repeated failed attempts to find a job led to loss of motivation and self-esteem. In 2013, a test group and a control group were randomly selected. The test group received the following interventions:

- Commitment device: Job-seekers signed their commitment to the job search programme on the cover page of a job booklet.

- $\quad$ Chunking: The job booklet guided job seekers to plan the specific job search activities, with the process broken down into a series of smaller tasks. In meetings with their caseworker every one to two weeks, accomplishments would be reviewed and feedback given to reinforce positive behaviour.

- Incentive: Those who completed five sessions or found a job received a SGD 100 (about USD 80) voucher.

- Social norms and priming: The consultant rooms were re-designed with visual representation of the number of successful job seekers and information about "hot jobs" for motivation. Vacancy statistics and information about average salary ranges were displayed to nudge job seekers into adopting more realistic job expectations.

The job-finding rate after three months was $53 \%$ higher in the treatment group than in the control group. Jobseekers developed a stronger sense of ownership and accountability, and the increased frequency of meetings, along with the structured job search process, had nurtured stronger and more positive relationships between career consultants and job seekers.

Source: OECD (2017d), Behavioural Insights and Public Policy: Lessons from Around the World, OECD Publishing, Paris.

\section{Wage bargaining}

National-level collective agreements extended by law to cover around $90 \%$ of workers, the previous norm in Finland, is ending after the Finnish Confederation of Industries decided to unilaterally terminate all central-level agreements in 2017. The new Sweden-inspired "Finnish model" agreed in principle as part of the competitiveness pact implies a move towards a system where sector-level collective agreements are coordinated following the lead of export industries. Such a system can yield efficient macroeconomic outcomes while increasing the flexibility to adjust relative wages between sectors. The government has taken steps to increase the scope for firm-level bargaining, leaving room for local agreements better suited to local conditions and the needs and preferences of individual workers and employers. Successful examples of such "organised decentralisation" of wage bargaining can be found in Sweden, Germany and Norway, among others (OECD, 2017a). These systems generally perform better in achieving efficient macroeconomic outcomes than in adapting relative wages between sectors and professions, but can 
contribute to constructive labour relations and flexibility at the different bargaining levels (Pareliussen et al., 2018a). Wage increases can for example be traded for more flexible working time arrangements in order to adapt production better to fluctuations in demand and input prices.

However, attempts to decentralise the Finnish bargaining process from 2007 to 2010 contributed to eroding competitiveness, as coordination broke down. Institutionalising the sequence of negotiations with exporting sectors taking the lead, strengthening the state mediator and strengthening the process to build a common understanding and common analyses of the underlying facts, fundamentals and a reasonable level of overall wage growth, would increase the likelihood of efficient overall wage growth. However, the strength and resilience of wage bargaining institutions depends on their ability to repeatedly prove their usefulness and build trust by securing fair, efficient outcomes and peaceful, constructive labour relations. Wage negotiations taking place in 2017 and 2018 will be the first test of the new Finnish model (OECD Economic Survey of Finland, 2016; OECD, 2017a). Sectoral agreements concluded so far have been in line with the example set by exporting industries and are expected to slightly improve price competitiveness. Coordination hence seems to work despite the failure to reach a formal agreement on a Finnish wage bargaining model.

\section{Employment protection legislation}

The OECD Economic Survey of Finland 2016 pointed to restrictions to hiring workers on temporary contracts and a short trial period as an impediment to hire, as employers had little opportunity to test the capabilities of new hires. The trial period has since been extended, and conditions for hiring on temporary contracts eased. Furthermore, strict regulation of individual dismissals induces costs and uncertainty, potentially harming productivity by impeding efficient flows of human capital. At the margin, flexibility in traditional employment contracts will affect firms' decisions to hire on temporary or regular contracts, but it will also affect the choice between hiring or buying services from freelancers. Flexible employment protection combined with a solid and flexible social safety net is thus the best option to provide stable and secure situations for workers in general.

\section{Summary and recommendations}

The combination of different working-age benefits, childcare costs and income taxation creates complexity, reduces work incentives and holds back employment. Major disincentives in Finland are related to tapering rules for unemployment benefits, social assistance and the housing benefit, the extended unemployment benefit for older workers, the childcare fee structure and the homecare allowance. Improved benefit design combined with efficient activation policies can reduce complexity, remove the strongest disincentives and make the benefit system more robust to changes in working life. Comparing two different scenarios: a uniform benefit for all ("basic income") and a universal tapering rule ("universal credit"), shows that the general direction of reform matters, and leads to considerable differences in incentives, inclusiveness and affordability.

The current benefit system targets transfers according to peoples' needs and circumstances. For this reason, replacing current benefits with a basic income would lead to a drastic redistribution of income and likely increasing poverty, even though a basic income would entail a simplification and could improve incentives for some.

Merging working-age benefits with similar aims and coordinating their tapering against earnings would on the other hand drastically improve work incentives and transparency, while preserving or strengthening social protection. Moving the benefit system step by step in this direction therefore seems to be a solution better adapted to Finland than implementing a basic income. Once the new income registry comes online, linking benefit payments to real-time incomes, combined with strengthened work incentives 


\section{ECO/WKP(2018)15}

and a strong activation framework, would make for a truly efficient and inclusive benefit system, fit for the future of work.

\section{Recommendations to reform working-age benefits}

\section{Main recommendations}

Harmonise working-age benefits and coordinate their tapering against earnings.

Upon completion, use the income registry to adjust benefits to income in real-time.

Use the income registry to provide better tools for clients to evaluate the financial consequences of their work decisions.

Restructure the homecare allowance to foster participation in childcare and incentivise employment.

Calculate childcare fees on individual incomes.

Increase the age threshold for extended unemployment benefits at least in line with the statutory pension age.

\section{Further recommendations}

Strengthen employment services.

Ensure a stepwise and gradual transition and adequate resources in connection with the regional reform. 


\section{BIBLIOGRAPHY}

Ahtiala, P. and J. Junttila (2015), "The collapse of Soviet trade and Finland's Great Depression of the 1990's: A re-examination”, SSRN Electronic Journal.

Bassanini, A. and R. Duval (2009), "Unemployment, institutions, and reform complementarities: Reassessing the aggregate evidence for OECD countries", Oxford Review of Economic Policy, Vol. 25, No. 1 .

Browne, J. and H. Immervoll (2017), "Basic income as a policy option: Illustrating costs and distributional implications for selected countries", Technical Background Note.

Causa, O. and M. Hermansen (2017), "Income redistribution through taxes and transfers across OECD countries", OECD Economics Department Working Papers, No. 1453, OECD Publishing, Paris. http://dx.doi.org/10.1787/bc7569c6-en

Department for Work and Pensions (2011), Universal Credit: Welfare that Works - Impact Assessment, (revised), London.

Department for Work and Pensions (2016), Universal Credit Evaluation Framework 2016, DWP Ad Hoc Research Report, No. 34, London.

Department for Work and Pensions (2017), Universal Credit Employment Impact Analysis - Update, DWP Ad Hoc Research Report, No. 53, London.

Economic Policy Council (2015), Economic Policy Council Report 2014, Economic Policy Council, VATT Institute for Economic Research, Helsinki.

Economic Policy Council (2017), Economic Policy Council Report 2016, Economic Policy Council, VATT Institute for Economic Research, Helsinki.

Eerola, E. and T. Lyytikäinen (2017), "Housing allowance and rents: Evidence from a stepwise subsidy scheme", VATT Working Papers, No. 88, Helsinki.

ETUC (2016), Towards New Protection for Self-Employed Workers in Europe, European Trade Union Confederation Resolution.

Eurofound (2017), Drivers of Recent Job Polarisation and Upgrading in Europe, European Jobs Monitor 2014, Luxembourg.

European Commission (2017), Country Report Finland 2017, Commission Staff Working Document, No. 2017/91, Brussels.

Fimreite, A. et al. (2012), "Joined-up-government: Reform challenges, experiences and accountability relations", Uni Rokkan Centre Working Paper No. 6-2012.

Goos, M., A. Manning and A. Salomons (2009), "Job polarization in Europe", American Economic Review, Vol. 99, No. 2. 
Gould, R. and L. Saurama (2017), "From early exit culture to the policy of active ageing", in: De Vroom, B. and E. Øvrebye (eds.), Ageing and the Transition to Retirement: A Comparative Analysis of European Welfare States.

IFS (2016), The (changing) effects of universal credit, in IFS Green Budget 2016, Institute for Fiscal Studies, London.

Kela (2016), "From idea to experiment, report on universal basic income experiment in Finland", Kela Working Papers, No. 106, Helsinki.

Kotamäki, M. (2016), "Participation Tax Rates in Finland, Earnedincome Tax Credit Investigated," Aboa Centre for Economics Discussion Papers, No. 107, Turku.

Kotamäki, M., J. Mattila and J. Tervola (2017), "Turning static pessimism to dynamic optimism. An exante evaluation of unemployment insurance reform in Finland", Kela Working Papers, No. 124, Helsinki.

Kyyrä, K. et al. (2017a), "The spike at benefit exhaustion in the Finnish labor market”, VATT Working Papers, No. 86, Helsinki.

Kyyrä, K. et al. (2017b), "Unemployment insurance in Finland: A review of recent changes and empirical evidence on behavioral responses", VATT Research Reports, No. 184, Helsinki.

Kyyrä, K. and H. Pesola (2017), "Long-term effects of extended unemployment benefits for older workers”, VATT Working Papers, No. 89, Helsinki.

Ministry of Finance (2014), Europe 2020 Strategy, Finland's National Programme, Spring 2014, Ministry of Finance Publications, 16c/2014, Helsinki.

Ministry of Finance (2017a), Regeringens Proposition till Riksdagen om Statsbudgeten för 2018 (The Government's Proposal to Parliament on the 2018 State Budget), Helsinki.

Ministry of Finance (2017b), Europe 2020 Strategy, Finland's National Programme, Spring 2017, Ministry of Finance Publications, 18c/2017, Helsinki.

Moe, C., and T. Päivärinta (2013), "Challenges in information systems procurement in the public sector", Electronic Journal of e-Government, Vol. 11, No. 2.

National Audit Office (2013), Universal Credit: Early progress, NAO reports, London.

OECD (2013), OECD Employment Outlook 2013, OECD Publishing, Paris. http://dx.doi.org/10.1787/empl_outlook-2013-en.

OECD (2015), OECD Employment Outlook 2015, OECD Publishing, Paris. http://dx.doi.org/10.1787/empl_outlook-2015-en.

OECD (2016a), "New forms of work in the digital economy“", OECD Digital Economy Papers, No. 260, OECD Publishing, Paris. DOI : http://dx.doi.org/10.1787/5jlwnklt820x-en.

OECD (2016b), Finland 2015, Country chapter for the OECD series Benefits and Wages, www.oecd.org/els/social/workincentives, accessed 7 September 2017. 
OECD (2016c), PISA 2015 Results (Volume I): Excellence and Equity in Education, OECD Publishing, Paris. http://dx.doi.org/10.1787/9789264266490-en.

OECD (2016d), OECD Employment Outlook 2016, OECD Publishing, Paris. http://dx.doi.org/10.1787/empl_outlook-2016-en.

OECD (2016e), Back to Work: Finland: Improving the Re-employment Prospects of Displaced Workers, OECD Publishing, Paris. http://dx.doi.org/10.1787/9789264264717-en.

OECD (2016f), Job Creation and Local Economic Development 2016, OECD Publishing, Paris. http://dx.doi.org/10.1787/9789264261976-en.

OECD (2017a), OECD Employment Outlook 2017, OECD Publishing, Paris. http://dx.doi.org/10.1787/empl_outlook-2017-en.

OECD (2017b), "Basic income as a policy option: Can it add up?", Policy Brief on the Future of Work, OECD Publishing, Paris.

OECD (2017c), Getting Skills Right: Skills for Jobs Indicators, OECD Publishing, Paris. http://dx.doi.org/10.1787/9789264277878-en.

OECD (2017d), Behavioural Insights and Public Policy: Lessons from Around the World, OECD Publishing, Paris.

OECD Economic Survey of Finland (2016), OECD Economic Surveys: Finland 2016, OECD Publishing, Paris. http://dx.doi.org/10.1787/eco_surveys-fin-2016-en.

OECD Economic Survey of Finland (2018), OECD Economic Surveys: Finland 2018, OECD Publishing, Paris. http://dx.doi.org/10.1787/eco_surveys-fin-2018-en.

OECD/ILO (2017), Engaging Employers in Apprenticeship Opportunities: Making It Happen Locally, OECD Publishing, Paris. http://dx.doi.org/10.1787/9789264266681-en.

Pareliussen, J. (2013), "Work Incentives and universal credit: Reform of the benefit system in the United Kingdom", OECD Economics Department Working Papers, No. 1033, OECD Publishing, Paris. http://dx.doi.org/10.1787/5k49lcn89rkf-en.

Pareliussen, J., H. Viitamäki and H. Hwang (2018a), "Basic income or a single tapering rule? Incentives, inclusiveness and affordability compared for the case of Finland", OECD Economics Department Working Papers, forthcoming, OECD Publishing, Paris.

Pareliussen, J. et al. (2018b), "Income inequality in the Nordics from an international perspective", Nordic Economic Policy Review 2018, forthcoming, Nordic Council of Ministers, Copenhagen.

Pärnänen, A. and O. Kambur (2017), "Finland/Sweden comparison: No great differences in working among mothers of small children", Tieto\&trendit, No. 3/2017, Statistics Finland, Helsinki.

Sarvimäki, M. (2017), "Labor market integration of refugees in Finland", Nordic Economic Policy Review 2017, Nordic Council of Ministers, Copenhagen.

Taylor Review (2017), Good Work: The Taylor Review of Modern Working Practices, Independent review commissioned by the United Kingdom Department for Business, Energy and Industrial Strategy. 